\title{
On Pronouns in Oratio Obliqua and Kindred Constructions.
}

\section{THOMAS BENTON McCARTNEY, Jr., A. B.}

$$
1 .
$$

A Dissertation Presented to the Faculty of the University of Virginia, June 1902, as a Part of the Requirements for the Degree of Doctor of Philosophy.

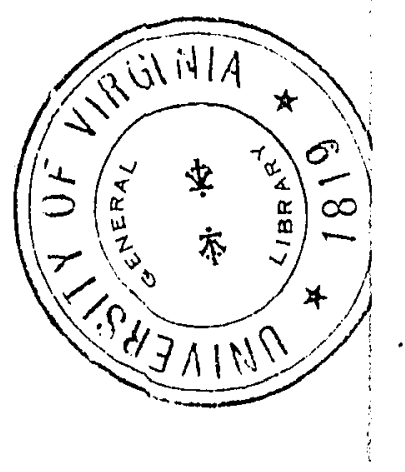


g1:

t)

U. Va. Doctoral

Dissertation

29

aj)

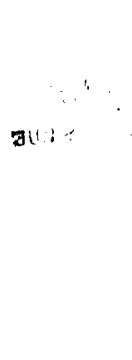




\section{Introduction.}

It has frequently been said that 'he who knows Oratio Obliqua knows Latin.' 'This is doubtless not the whole truth. A fact universally recognized, however, is that much careful, painstaking study is requisite for the mastery even of the general principles of this very complicated subject. In this study three points, especially, have to be considered carefully: the use of Hood, the nse of Tense, and the use of Pronouns. Modern research of eminent scholars has done much to elucidate the principles and excmplify the rules governing the Oratio Obliqua expression from these sereral standpoints; but the whole subject has not as yet received the exhaustive, minute study that its relative importance demands. This is true in particular of the use of Pronouns-without doubt the most intricate of the three questions presented, and the one most difficult to reduce to rigid grammatical rule. The inadequate discussion of Pronoums found in oven the most excellent of our grammars is the best apology for this disscrtation. The subject is usually dispatched in a few paragriphs or at most a few pages. The elementary principles are stated sometimes vaguely, sometimes dogmatically, and never with sufticient fullness. We are told, for instance, that ipse may be used almost at will for the Reflexive; that the Reflexive is sometimes used for the Demonstrative and vice versa, and that these exceptional uses are very frequently due to the author's whim or curelessness of style. From the large majority of English, French, and German grammar's one can got but little more knowledge of the subject. Ot the Iinglish grammars Roby's is perbaps the best ; of the German, Kübner's or the Billroth-Ellendt. In these the exposition is fuller and more definite. Riemann and Kühnast in their works on the grammar of Livy trent the subject with greater exactness and claboration of details, but in general they contine their investigations to Livy alone. The most satisfactory presentation in Lnglish of the principles governing the whole sphere of pronominal 


\begin{abstract}
4
reference in Oratio Obliqua is the succint, exact discussion found in Peters' Syntaw of the Latin Verb.

To many of the school grammars in common use, to the notes in the best editions of the authors studied, and to the works just mentioned, I am inclebted for many eximples and suggestions as to the interpretation of certain unusual or irregular constructions; but the conclusions drawn and the rules deduced are in largest part the result of careful investigation and study of Latin anthors for the purposes of this dissertation. As it was not possible to study with any degree of thoroughness the whole range of Latin prose, the Historitus were selected as the best field for investigation. This investigation has embraced the whole of Caesar (with Auct. B. G. VIII, B. Afr., B. Hisp., and B. Alex.), the whole of Sallust, of Nepos; most of Livy, of Tacitus, and of Curtius ; parts of Suetonius, Velleius, and Val. Maximus. Numerous examples from Cicero have been added for comparison, but for this purpose only a few Orations and Letters, and portions of de Off., de Invent., and de Div. have been read. Citations from any authors not rend or parts of works not studied bave been borrowed without scruple from every available source. All the abbreviations used are self-explanatory. In references the name of the author quoted is frequently omitted as unnecessary. Thus, B. G. for Caes. B. G.; Cat. or Jug. for Sall. Cat., Sall. Jug. The Lives of Nepos are cited by numbers.
\end{abstract}




\section{Pronouns in Oratio Obliqua.}

In this dissertation the term Oratio Oblicua will be used in its widest application to include indircet statcment of words, thought, or feeling, whether formally expressed, as when the leading clause is the Acc. with Inf. construction; or merely implied or imputed, as in clauses introduced by qui, by quod, quia, etc. The discussion will include also constructions closely allied in sense to subordinate clauses of Indirect Disconrse-Indirect Questions, clauses of Purpose or Design, clauses introduced by the conjunctions quin, quominus, etc.and will treat, besides, the use of the Pronouns in clauses containing a Participle, a Gerund, or an Infinitive (as with intoco)-clauses which are not, it is true, in the sphere of Oratio Obliqua proper, but which admit of treatment as Abridged Propositions more or less remotely akin in meaning to subordinate clauses in the Indirect Discourse. In a word, this treatise ains to exemplify the uses of Pronouns, especially the Retlexive, the Demonstrative is, and the Intensive and Distinctive ipse, in all dependent clanses of Subjective conception, expressed as a rule in the Subjunctive Mood.

\section{The Reflezive.}

IN O. R.

The Reflexive is the Pronoun of Subjective reference. Its primary and regular use is to refer to the Subject of the clause in which it is tound. This subject may be Grammatical: B. G. 2, 2t, 2 fugae scse mandabant. B. C. 3, 97, 3 Caesar copias suas divisit-or it may be Logical: Nep. 14, S, 3 spes omnis consistehat Datami in se (- Datrmes sperabat). Liv. 29, 1, 17 suas res Syracusanis restituit (= Syracusani rece. perunt). It is necessary to exemplify further the reference to a Logical Subject, as this principle explains many apparent anomalies in Oratio Obliqua. This use of the Reflexive to refer to a word which, though not in the Nominative, is yet 
essentially the Subject of the sentence, as being the real author of the action expressed by the verb, or the person most prominently in the mind of the author, obtains especially in the following cases :

(1) When the rerb is Limpersomal:-Cic. in Verr. I, 12, 35 sunt homines quos libiclinis infamiacque suac neque pudeat necpe taedeat.-Nep. 13, \&, 1 cum populum indicii sui pacniteret.

(2) Reforring to an implied Intufinite subject, "one":Cic. de Off. 1, 39, 5 habenda ratio non sua (one's own) solum, sed etiam aliorum.-Liv. $7, \pm 0,2$ ultima rabies secessio ab suis habcbatur.

(3) To an oblique case of quisque:-Cic. de Off. 3, 10, 42 suae cuique utilitati serviendum est. De Amicit. 15, 55 anicitiarum sua cuique permanet stabilis possessio.

$(t)$ In the Prepositional Phrases per se, inter se, and the like :-Liv. $5,4 \$, 9$ rei foedissimae per se. $6,38,5 \mathrm{cer}-$ tamine inter se tribunorum. -Often also with other prepositions and especially cum:-B. C. 3, 24, 3 quadriremem cum remigibus defensoribusque suis ceperunt. - In some instunces these phrases are, in eflect, abridged subordinate clanses, and the reference of the Reflexive to the real subject can be made obvious by restatement in some expanded form. Se page 30.

(5) With the Gerund, the Infinitive, and the Participle, particularly in the Ablative Absolute construction. As here also we ustailly have the equivalent of a subordinate clause, the Pronouns in these expressions will be discussed with those in clatses allied in sense to the Oratio Ohliqua.

(6) Sometimes the Logical subject must be infer red from the context:-Cic. Verr. 2, 13, 33 haec omnia isto prietore non modo perturbata, sed plane et Siculis etcivibus Romanis erepta: primum suce leges (- suas leges amiserunt).-Liv. 39, 55, 3 quod vero etiam sua reddiclerint (sc. iiss).

It should further be noter that the Possessive suns is used more freely than the Pronoun sur, sibi, se. In particular, suess is often used in an emphatic sense meaning his, her, their, one's own, as opposed to alionus (- belonging to others), and ca 


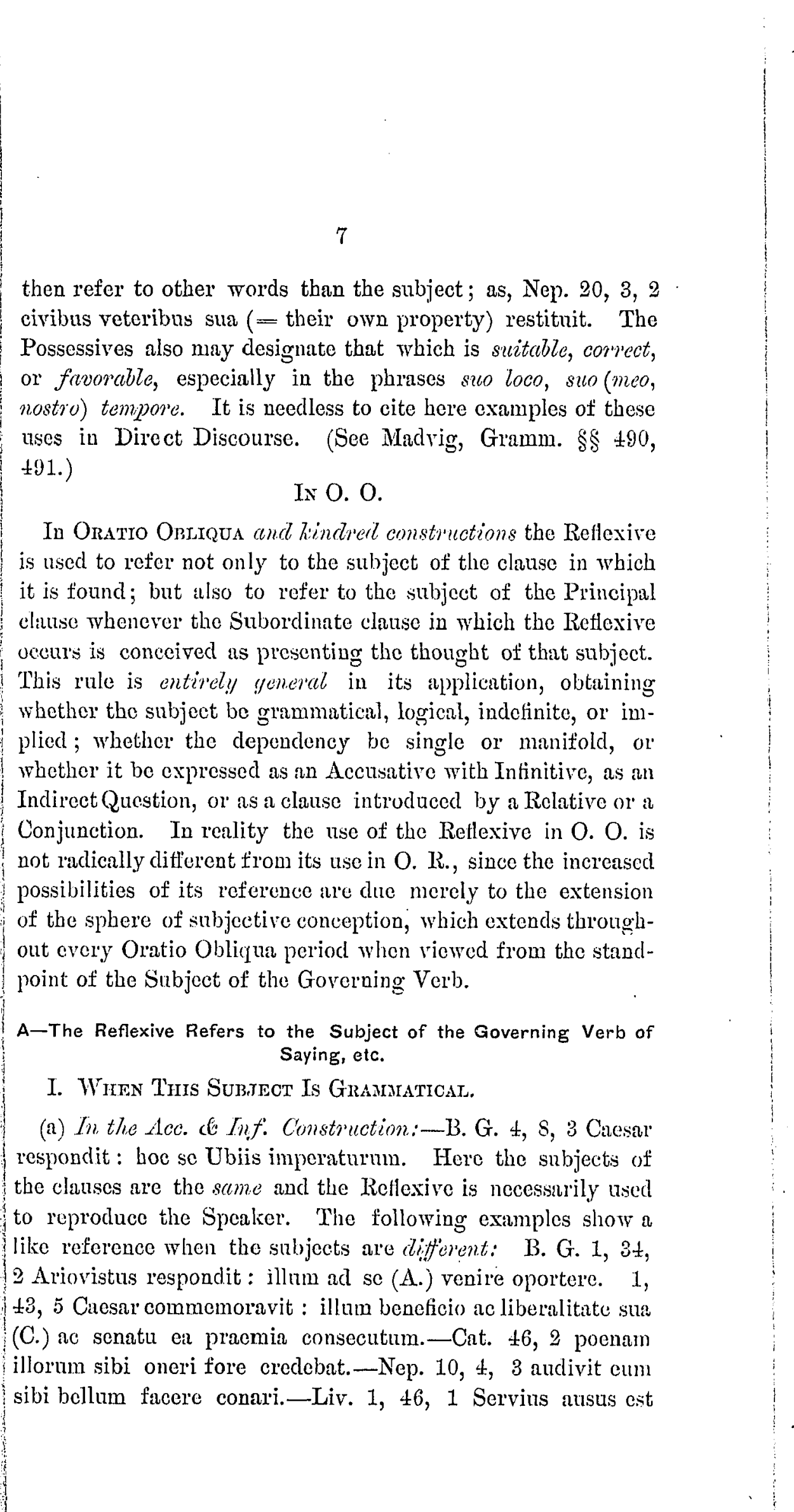


ferre ad populum vellent iuberentne se regnare.-Tac. Ann. 3, 69 disseruit Caesar : Non quidem sibi ignara, quae de Sileno vulgabantur. - Of course also in a Rhetorical Question: Liv. 24, 26, \& (Heraclia dixit): quod ab se cuiquam periculum esse?

(b) With Simple Suljunctive (Imperative):-Nep. 2, 7, 3 (Themistocles Lacednemoniis dixit): interea se obsidem retinerent. 2, 7, 6 Quare se remitterent.

(c) Indirect Question:-B. G. 1, 47, 6 (Ariovistus) conclamavit, quid ad se venirent. -Cat. 51, 7 quid se dignum foret, qunerebant.-Jug. 109, 1 edocet quae sibi responderentur.Liv. 23, 27, 10 Hasdrubal litteras mittit, indicans, quanto fama profectionis suae damno fuisset.

(d) Clauses introduced by a Conjunction or Relative presenting the thought of Governing Verb:-[ut] B. G. 1, 47, 5 His mandavit, ut, quae diceret Ariovistus, ad se referrent. 4, 16, 5 Ubii orabant, ut sibi auxilium ferret.-B. C. 3, 60, 1 (Cresar) illos castigavit monuitque, ut ex sua amicitia omnia exspectarent et ex praeteritis suis officis reliqua sperarent. Cat. 21, 5 Catilina colortatus, ut petitionom suam curae haberent, conventum dimisit.-Nep. 15, 8, 1 Quibus ille permisit, ut omnem causam in se transferrent suaque opera contenderent, etc.-Liv. 21, 4, 2 (Hannibal) effecit, ut pater in se minimum momentum ad favorem conciliandum esset.[ne] Liv. 31, 41, 8 itaque ne (Pure Purpose) temeritas eorum negligentiaque sibi ac suis etiam cladis alicuius causa esset, tumulum cepit.-Nep. 4, 4, 6 Pausanias orare coepit, ne (Complementary Final) cnuntiaret nec se proderet. 10, 8, 5 Ille concitatus est, verens, ne (Fear) consilium aperiretur suum. - [neve, neu $]$ B. C. 1, 76, 1 Petreins milites, neu se neu Pompeium imperatorem suum trudant, obsecrat.-[quo] Cat. \pm 9 , 4 ut nonnulli equites Romani, quo studium suum clarius esset, Cacsari minitarentur. - Nep. 2, 8, 4 (Themistocles), quo maiore religione se tueretur, filiam eius parvulam arripuit.-[ [quin] Liv. 25, 19, 1 Hannibal copias eduxit handquaquam dubius, quin multo minus sc sumque exercitum sustinere Romani possent.-[quominus] Cic. Deiot. 13, 35 (Deiotarus), quominus a se, qui in altera parte fuisset, ea sumeres, non recusavit. [yud $]$ B. G. 1, 41, 2 decima legio ei gratias egit, quod de se 
optimum iudicium fecisset. $7,19,4$ indignantes milites, Cilesar, quod conspectum sum (= militum) hostes perferre possent..... edceet, etc.-Nep. 17, 5, 2 (Agesilaus) tantum afuit ab insolentia glorite, at commiseratus sit fortunam Graeciac, quod tam multi a se victi vitio adversariorum concidissent._Liv. 1, 21, 3 lucum sacravit, quod ibi concilia cum coniuge sua Egeria essent. 21, 39, 8 Scipionem Hannibal eo ipso, quod adversus se dux lectus esset, praestantem virum credebat.-[ctum] Cat. 14,6 (Catilina) neque sumptui neque modestiae suac parcere, dum (Conditional Wish) illos obnoxios tidosque sibi faceret.-[minusquan] B. G. 8, 1t, 2 (duces) coplas instruunt, no prius Romani persequi se inciperent, quam longius agmen impedimentorum sum um processisset.-Nep. 1s, 3, 6 prius in aciem excrcitum duxit, quam milites sui scirent, etc. The Roflexive in these sentences is entirely regular, as pritusquam is here clearly Final, though by no means always so.-[quasi, velut, etc.] Cic. Quint. 2, 9 Qui quasi sua res agatur, ita Naevii studio morem gerunt.-Nep. 13, 3, 4 at ille non cessit auctoritati, velut in sua manu esset furtuna. - [qui] Jug. 13, 3 (Adherbal) legatos miserat, qui (Final) senatum docerent de caede fratris et fortunis suis. Cf. Liv. 23, 7,7 misit qui vocarent Magium ad sese in castra. - Cic. ad Att. 2, 1, 12 Pactus omnes libros, quos frater suus reliquisset, milhi donavit (Implied O. O.).-[si,ni, etc. $]$ Cat. 23,3 (Curius cocpit) minari ferro, ni sibi obnoxia foret.

II. The Reflexive Refers to the Logical Subject of Governisg Verb.

(1) In such references the real subject is apparent when the elements of the clatse are restated :-B. G. 5, 53, 6 (Cacsar) ab Lucio Roscio certior factus est (= Caesari Lacius nuntiavit), magnas Gallorum copias oppugnandi sui (L.) causa conrenisse neque longius millia passmum octo ab hibernis suis (L.) afuisse.-Nep. 14, 9, 2 cum ei nuntiatum esset (- audivisset), quosdam sibi insidiari. $4, \pm, 1$ eique in suspicionem venisset (=- suspicatus esset), aliquid in ea de se esse scriptum.-Liv. 1, 5, 5 Faustulo spes fuerat (= Faustulus speraverat), regiam stirpem apud se educari. $\quad 2,31,11$ apparuit causa plebi, sum 3 
vicem indignantem magistratu abisse (i. e., the commons believed that he had abdicated from indignation at the treatment they had received. Cf. $45,32,4$ id apparuit multitudini pro libertate sua esse factum). 2, 37, 9 proliciscentibus deinde indignatio aborta, se ut sceleratos abactos esse (-. proficiscentes indignati sunt). 22, 56, 7 litterte allatae sunt ab $\mathrm{T}$. Otacilio: nuntiatum sibi cssc aliam classem ad insulas stare (= Otercilius seripsit). Cf. 35, 6, 1 litterae allatae sunt Q. Minucii (=: Minncius scripsit): comitia suae sortis esse. See also in Livy : 9, 16, 3 ad se ; 26, 45, 5 suis ; $37,33,5$ sibi; 41,10 , 2 sibi $; 2,47,8$ se. $8,35,1$ concensus populi Romani ad obtestationem versus ( $=$ populus obtestabatur), ut sibi poenam magistri equitum dictator remitteret-shows the same reference of the Reflexive in a Complementary Final ut-clause. Examples from Ciccro of reforence to a Logical subject are:ad Att. 2, 16, 3 a Cacsare invitor (= Caesar me invitat), sibi ut sim legatus. $6,1,5$ numquam enim ex illo audivi $(==$ ille mihi dixit), illam pecuniam esse stam. Cf. pro Milon. 16, $\pm \frac{1}{x} \operatorname{ros}$ ex M. Faronio audistis ( $=$ vobis M. Favonius dixit), Clodium sibi (F.) dixisse periturum Milonem triduto. - We may add also Plaut. M. G. 3, 1, 205 a taa mi axore dicam delatum et datum $(=$ tuam uxorem mi dedissc), ut sese (= uxorem) ad cum conciliarem.

(2) This Logical subject may be only implied:-Cic. Verr. $5,22,58$ testimonio sunt, se etc. $=$ testuntur sc.-Jug. 83 , 1 quia stultitiae [sc. Mario] videbatur alienam rem periculo suo curare, legatos mittit. -Also in a Secondary (Dependent) $O$. O. clause of Purpose :-Jug. 111, 1 (Sulla) patefecit: fiucicndum [sc. Boccho] esse aliquid, quod ( $=$ nt id) illorum magis quam sua rettulisse videretur. It will be noted, howerer, that in these examples sute may mean "his mon"--suo opposed to alienam and sna to illorum. This reference to a subject inferred from the context, though rare in other authors is freely used by Livy, as the following examples attest: 2, 46, 1 prope certa spes erat [sc. cis], non magis secum pugnaturos quam pugnarint cum Acquis (= =ertam spem babebint). In $3,47,2$ the Reflexive refers to the Implied Logical subject of the Primary O. O. clause: (Verginius dixit) quid prodesse 
[eis], si, quae timeantur, liberis suis (O. R. vestris) sint patienda? The following are examples in subordinate clatuses: 7 , 37, 10 quia multitudo sua hatud procul ab inopia esset, placuit [sc. ducibus = decreverunt duces] militem duci. 23, 10, 10 extemploque (Magius) Carthaginem missus [sc. ab Hamnibale $==$ Hannibal Magium misit], ne offendendi sibi (H.) novi socii. 36, 5, 6 hac legatione [sc. Epiratorum] id agi apparebat, ut integra sibi omnia essent. $31,15,3$ in litteris [sc. eius] commemoratio erat beneficiorum primum storum, ad postremum adhortatio capessendi belli, dum se haberent $(=$ commemoralnat ......adhortabatur). Cf. $40,23,8$ deprecatio in litteris erat [sc. T. (Quinctii], si quid adulescens sceum ( $=$ cum (Quinetio) egisset, etc.

This reference to a Logical subject expressed or implied has been thus fully exemplified to show the wide application of the principle. In fact, as regards reference to the subject of the Governing verb, the construction according to sense is the rule, and the construction according to form the comparatively rare exception. Only a few of these exceptions need be noted :-Liv. 23, 19, 5 Gracchts, quia praedictum erat dictatoris, ne quid absente en rei gereret, nihil movebat (where se might be expected, with pracelictum erat dietatoris =- pracdixerat dictator ; but Gracchus is most prominent in the mind of the Writer, and the Subordinate clause is stated Objectively (by eo) and not from the standpoint of the dictator. -Cic. Div. in Cacc. 20, 65 delectus sum ab universa provincia, qui eius iura fortunasque denfenderem (where sua conld stand, with al provincic as Log. Subj.). Ad Quint. Fr. 2, 15, 1 (litterae Caesaris clatae) quarum initium est, quam stavis ei (C.) tuus adventus fuerit... . deinde se (C.) effecturum, ut etc. (where the Writer passes trom the formal ei to the logical se).

III. The Reflexive Rerens to an Indefinite Subiect.

This reference, which is found principally in Cicero and Livy, most frequently obtains in Infinitive clauses, more or less closely related to regular 0 . O. The Reflexive here, however, usunlly refers to the Implied subject of the Infinitive, 
not to that of the Governing verb :-Jug. 3, 3 neque aliud se (=one's self) fatigando nisi odium quaerere dementiae est. -Cic. de Inv. 1, 43, 81 ant a se potius quam ab adversariis starc. Verr. 3, 72, 169 quanto est honestius alionis iniuriis quam sua commoveri (sua = me's own and is also in contrast with alienis). Acad. 1, 4,16 non arbitrari sese scire, quod nesciat, etc. De Off. 1, 38, 137 deforme est etiam de se ipsum praedicare (where se, one's self, refer's grammatically to the subject of the Intinitive, ipsum, which is itself Indefinite. Cf. de Amic. 22, 82 par est autem primum ipsim esse virum bonum (i. e., to be a good man one's self), tum alterum similem sui quacrere). Other examples from Cicero are: De N. D. 1, 44, 122 sun'um ; de Otf. 1, 28, 99 de se ; Parad. 6, 3, 51 suis rebus. - Livy $28,4 \pm, 1$ ab se (one's self) remoto periculo alium in discrimen adducere quale sit. 39, 5, 2 collegae plurimum oratio movit: ne stas quidem simultates pro magistru cxercere boni exempli esse (where suus = one's own, not referring to the Log. Subj., collegae, of the Governing verb). In $7,40,2$ ultimaque rabies secessio ab suis habebatur-suis probably means "one's people, country"; but it may be interpreted as referring to the Log. Subj. implied in babebatur. The meaning would then be : they thought that it was downright madness to secede from their people. - Tac. Dial. 6 quid enim dulcius libero et ingenuo animo quam videre plenam semper domum suam concursu splendidissimorum hominum? idque scire non pecuniae, sed sibi ipsi dari (where suam and sibi refer to an Indefinite Subjest implied in animo. -Seneca de Tranq. 1, 7 placet intra parietes suos coercere. Cornific. ad Her. $4,1,2$ illa relinquere et ad sua devenire.

The phrase sua sponte both in $O$. O. and elsewhere is frequently used in an entirely vague sense, but usually with reference in a general way to the subject of the sentence. But this subject may be (1) Inanimate, as in Liv. 2, 43,3 redibatque non sua sponte plebi mos detrectandi militum; $9,7,8$ iustitiumque in foro sua sponte coeptum; $9, \pm 1,17$ clamor sua sponte ortus; $10,36,3$ sua sponte pugma cocpit._-2, 23, 2 invidiamque eam sun sponte gliscentem calamitas accendit (referring to the Object; but the Participle may be expanded 
into a Relative cliuse, quae sua sponte gliscebat).-The subject may be (2) a Clause, as in Liv. 22, 38, 13 sua sponte apparebat (cum) tuta celeribus consiliis praepositurum; 35, $1+, \pm$ secutum tamen sua sponte est, ut, etc.

\section{Wimen There Is a Series of Dependencies.}

The reference of the Reflexive to the subject of a Gorerning Verb obtains not only where there is a Single Dependency, as in the citations that have been made, but also where there is a Series of Dependent Clauses. When the subjects of these clatwes are the same as that of the Governing verb, the Reflexire must of course be used, and it is unnecessary to quote eximples. When the subjects are different from that of the Governing verb, reference is still made by the Reflexive, with comparatively few exceptions, and these as a rule for good and obvious reasons.

(a) In a Teofold Dependency:-B. G. 1, 20, 2 (Divitiacus dixit): nec quemquam plus quam se doloris capere, propterea quod (ille) per se crevisset. 1,3t,2 Ariovistus respondit : si quid ille se velit, illum ad so venire oportere. 5, 27,3 Ambiorix locutus est: sua csse cius modi imperia, ut non minus haberet iuris in se multitudo quam, etc. [se stands here even in an $O$. O. clause of Result]. 4, 3, 1 putant hac re significari, magnum numerum civitatium suam vim sustinere non posse.-B. C. 1, 9, \& (Caesar dixit): retineri legiones duas, quae ab se sint abductae. -Cat. 31, 7 Catilina postulare coepit, ne existumarent sibi perdita republica opus esse. -Jug. 22, I Iugurtba respondit: populum Romanum neque recte neque pro bono facturum, si ab iure gentiun sese prohibuerit. -Sall. Hist. (Dictsch) 1, $41,2 \pm$ neque aliter rem publicam et belli finem [esse] ait (Sulla), nisi mancat ius iudiciumque omnium rerum penes se.-Nep. 7, 4, 1 ille postulabat, si quid de se agi vellent, potius de praesente quaestio haberetur, quam, cte. 15, 8, 1 quibus ille permisit, ut omnem cansam in se transferrent sutuque opera factum contenderent. 23, 12, 3 illud (Prusias) recusavit, ne id a se fieri postularent.-Liv. 3, 58, 8 (testis) nihilum deprecans, quin, si quam sucm noxam reus dicere posset, privatus iterum in se saeviret. $23,2,8$ 
(Calavius dixit) : eo se periculo posse liberare eos, si permittant sibi. 21, 23, 7 praedicant (se) puruisse imperio eius, cuius imperator suus volucrit. 26, 25, 13 precatique (Acarnanes) simul Lipirotas sunt, ut, qui suorum (= Acarwanum) cecidissent, cos uno tumulo contegerent.

(b) In a Threefold Dependency:-B. G. 7, 8, 4 (Vercingetorigem) Arverni obsecrant, [1] ut suis fortunis consulat neu se ab hostibus diripi patiatur, [2] pracsertim cum videat, [3] omne ad se bellum translatum. 7, 19, 5 (Caesal dixit): [2] cum sic animo paratos videat, [3] ut nullum pro sua laude periculam recusent, [1] summas so iniquitatis condemnari debere, nisi, cte.-Nep. 1, 3, 2 (Durius) putavit [1] se Graeca lingua loquentes sub saa retenturum potestate, [2] si amicis suis oppida tradidisset, [3] quibus se oppresso nulla spes salutis relinqueretur.-Liv. 2, 12, $12 \mathrm{cum}$ rex [1] circumdari ignes iuberet, [2] nisi expromeret, [3] quas insidiurum sibi minas per ambages iaceret. 2 $\pm, \pm S, S[1]$ facturos se quod rellet legati respondent ficle accepta, [2] ut remitteret erm, [3] si imperatores sui non comprobassent factum. There is practically a fourfold dependency here, as fide accepta $=$ si fides accepta esset.

(c) In a Fourfold Dependency:-B. G. 7, 5, 5 (Aedui) renuntiant, [1] se Biturigum perfidiam veritos revertisse, [2] quiluus [3] id consilii fuisse cognoverint, [t] ut...... Arverni se circumsistorent. - Liv. 22,56, 8 litterae allatae sunt ab T. Otacilio (= Otacilius scripsit): [1] nuntiatum sibi csse, [2] aliam classem stare paratam, [3] ut, [t] ubi se ad tuendam Syracusanam oram Poeni sensissent, Lilybaeum aggrederentur.

B. The Reflexive refers to a Governing Verb not the Introductory Verb of Saying, etc.

If a verb of Saying or: Thinking is made to depend upon another of the same kind, causing a double Oratio Obliqua, the Reflexives in the Suborclinate clauses mily refer either to the subject of the first, the Leading (Independent) Verb, or of the second, the Dependent Verb. Eximples of reference to the Leading Verb in such sentences are given above in $(b)$ and $(c)$ :-B. G. T, 8, 4; Liv. 22, 56, 8. (In B. G. 7, 19, 5 
and $7,5,5$ the subjects of the two verbs are identical.) Often, however, and perbaps more frequently, the Refiexives refer to the subject of the second, the Dependent, verb of Saying, Thinking, etc.-Cic. Verr. Act. I, 10, 26 nam hoc Verrem dicere aiebant, te non fato, sed opera sua (V.) consulem factum. Verr. Act. I, 14, 40 cum praescrtim platnum faccre possum, [1] C. Verrem dixisse, [2] se habere hominem potentem, cuitus fiducia provinciarn spoliaret neque [2] sitbi soli pecuniam quaerere, sed ita trienuinm illud praeturac Siciliensis distributum habere, [3] ut secum prneclare agi diceret, [4] si unius questum in rem suan converteret (where in a fourfold dependeney the Reflexives in the 2 nd, $3 \mathrm{rd}$, and 4 th refer to the subject of dixisse in the 1st Dependent clause).-B. G. 1, 35, 2 Calesar legatos mittit: Quoniam hanc gratiam referret, at in colloquium venire invitatus gravaretur neque cle communi re dicendum siti putaret, haec esse, quae, etc.-Liv. 23, 22, 7 cum T. Manlius esse etiamnunc eius stirpis virum diceret, ex qua consul minatus esset Latinum.... .enm sua manu se interfecturum (se, sua referring to consul, subj. of 2 nd Verb). Cf. also the following: Liv. 2t, 29, \& (Epicydes dixit): renuntiandum esse, Leontinos aequam censere liberos esse, rel quod in solo urbis sure (L.) tyrannus ceciderit, vel, etc. 26, 29, 4 (Siculi) affirmantes....quid iratum, quod Romam de se questum venisse Siculos sciat, facturum? 32, 11, 1 Charopas renuntiari iuhct: ita crederet (consul), ut sure (cons.) omnia potestatis essent. 42, 26, $6[1]$ mittendosque legatos censuerunt, [2] qui nuntiarent [3] senatum existimare, [4] non aequum eam faccre, [5] qui ab sociis suis non abstineret iniuriam (where the dependency is fivefold, but the Reflexive refer's rather to senatum than to the subject of censuerunt, though they are really the same).-In B. G. 4, 6, 3 Caesar cognovit: missas legationes ab nonnullis civitatibus ad Germanos invitatosque cos, uti ab Rheno discederent, omniaque, quae postulassent, ab se forc parata-se refers to the Logical Subject, civitates, in al civitatibus, and a verb of Saying is implied in legationes and in invitatos.

In fact, the Reflexive may refer in any part of the $O$. $O$. period to the subject of the verb on which its clause immedi- 
ately depends. Such reference almost always obtains whenever the clause in which the Reflexive stands expresses the thought of the subject of the clause immediately governing it, when the Reflexive would be employed also in the Direct form. Here belong:-B. G. 1, 9, \pm a Sequanis impetrat, ut per fines suos Helvetios ire patiantur (where suos refer's not to the leading subject nor to that of its own clause, but to the subject of patiantur, on which its clause depends). Cr. 2, 4, 2 sic reperiebat: Belgas solos esse, qui Tentonos Cimbrosque intra tines suos ingredi probibuerint.—Jug. 15, 1 legati respondent: Iugurtham ab senatu petere, ne $s e$ alium putarent ac, etc...... neu verba inimici ante facta suo ponerent.-Liv. 21, 45, 6 daturum se operam, ne cuius suorum popularium mutatam secum fortmam esse vellent (the Reflexives refer to Subj. of vellent). Liv. 42, 6, S shows the reference also from a 2 nd dependency :-(Apollonius dixit) : petere regem, [1] ut, [2] quae cum patre suo societas atque amicitia fuisset, en secum renovaretur.

\section{The Reflexive refers to the Subject of the Clause in which it} Stands.

On the other hand, as in the Oratio Recta, so in Oratio Obliqua and allied constructions pronominal reference to the subject of any clause must, within the limits of that clause, be made by the Reflexive.

(a) In O. O. Proper with Acc. C. Inf.:-B. G. 1, 36, 1 Ariovistus respondit: populum Romanum victis ad summ arbitrium imperare consuesse. $1,43,8$ (Cresar) docebat: populi Romani hanc esse consuetudinem, ut socios atque amicos non modo sui nihil deperdere, sed gratia, etc...... auctiores velit esse (where sui refers to socios atque amicos, subjects of its clause).-Jug. 20, \pm existumans Adberbalcm iniurias suas (-Adherbalis) manu vindicaturum. -Nep. 2, $\tau, 4$ (Themistocles) professus est: Athenienses deos publicos suosque patrios ac penates muris sacpsisse.-Liv. 2, 10, \& (Horatius) increpare omnes: servitia regum superborum suae libertatis immemores alienam oppugnatum venire (sucte to servitic $=$ servos).-Tac. Ann. 3, 69 disseruit Cacsar :..... neque posse 
principem sua scientia cuncta complecti.-Jug. 64, 2 (Metellus dixit): debere illi res suas placere (sucts to its Log. Sbj. illi).

(b) With the Subjunctive (Imperative):-B. C. 1, 9, 5 (Caesar dixit): proficiscatur Pompeius in suas provincias. 1, 13,1 decuriones docent: proinde habeat rationem periculi sui.-B. Alex. 23 Alexandrini legatos ad Caesarem mittunt: ut dimitteret regem transireque ad suos (= regis) pateretur. Liv. 23, 7, 6 Decius Magius vociferatus est: ut interfecto Punico prasidio restitucrent Romanis se.

(c) In Constructions Allied to O. O.:-B. G. 2, 21, 2 Caesar milites cohortatus, uti suac pristinae virtutis memoriam retinerent. 7, 29, 1 (Vercingetorix) consolatus cohortatusque est, ne se admodum animo demitterent. -Cat. 59, 5 (Antonius) rogat, ut meminerint se pro aris focisque suis certare.--Jug. 26, 1 Adherbali suadent, uti seque et oppidum Iugurthae tradat.-Nep. 19, 1, $3 \mathrm{cum}$ (legati) admonerent, liberis suis prospiceret, etc.-Liv. 2, 6, 2 Tarquinius orare Veientes Tarquiniensesque, ne se (Abl.) ortum, eiusdem sanguinis, extorrem egentem ante oculos suos perire sinerent (where se and suos refer to subject of sincrent. Cf. 2, 9, 1, a very similar passage in which se refers to the subject of the Leading verb : Tarquinii orabant, ne se oriundos ex Etruscis, eiusdem sanguinis nominisque egentes cxulare pateretur). Liv. 45, 4, 7 Paulo, ut se suaque omnia in fidem et clementiam populi Romani permitteret, tenclente.

Whenever in a Dependent clause containing a Reflexive ipse is used to qualify the subject, the Reflexive must always refer to the subject of the Dependent, not the Leading elause: $B$. G. $7,20,3$ persuasum loci opportunitate, qui se ipse sine munitione defenderet. 7, 52, 1 Cresar temeritatem militum reprehendit, quod sibi ipsi indicavissent, quo procedendum, ctc. -Nep. 4, 4, 3 Neque prius (Laceduemonii) vim adhibendam putaverunt, quam se ipse (Pausanias) indicasset. Liv. 27, 3, 2 Flaccus (milites) sibimet ipsos tecta militariter coegerat aedificare. Cf. 2, 12, 7 (Mucius) timens sciscitari, uter Porsenna esset, ne ignorando regem semet ipse aperiret, etc., and Nep. 25, 22, 2 cum Agrippa [Atticum] obsecraret, ne id, quod natura cogeret, ipse sibi acceleraret. 
D. Double Reference.

Of course it frequently happens that in a single $O$. period two or more Reflexives are found referring to different subjects, according to the various rules above stated. These Reflexives may occur in diflerent clauses or in the same clause, often standing side by side. In such cases the Latin writers usually made no effort to shun an apparent ambiguity, since the context and the general sense of the passage make plain the reference in each instance to the proper subject.

Cic. Verr. II, 1, 47, 124 itaque ei Verres possessionem hereditatis negat se (V.) daturum, ne posset patronum sum (to ei) proscriptum iuvare. De Or. 2, 67 ut meminisset opera sua (Salinatoris) se (Maximum) Tarentum recepisse.-B. G. 1, 44, 8 Ariovistus ad postulata Caesaris respondit: Quid sibi vellet? cur in suas possessiones veniret (sibi refers to Subj. of its own clause, sucas to subj. of Leading verb). 1, 36, 2 Ariovistus respondit: si ipse populo Romano non praescriberet, quemadmodum suo (pop. R.) iure uteretur, non oportere sese (Ariov.) a populo Romano in suo (Ariov.) inre impediri. 1, 47, 1 Ariovistus ad Caesarem legatos mittit: si id minus vellet, e suis (C.) aliquem ad se (A.) mitteret.-B. C. 1, 19, 4 Pompeius rescripserat..... . neque suo (P.) consilio aut voluntate Domitium se (D.) in oppidum contulisse. 1, 22, 6 Lentulus petit, quod de suc salute impetraverit, fore etiam reliquis ad suam spem solatio (where sua refers to Lentulus and suam to reliquis, the Log. Subj. of fore $=$ id habituros reliquos, etc.). 3, 107, 2 (Caesar) ostendit, sibi (C.) placere, Ptolemaeum atque Cleopatram de controversiis iure apud se (C.) potius quam inter se ( $\mathrm{Pt}$. and $\mathrm{Cl}$.) armis disceptare. - Nep. 2, 7, 4 ('Themistocles) professus est : Athenienses suo (Th.) consilio deos publicos suosque (Ath.) patrios muris saepsisse. 2, 7, 6 [Themistocles Lacednemoniis dixit]: Quare, si suos (Lac.) legatos recipere vellent, se (Th.) remitterent. 23, 12, 2 patres legatos miserunt, qui ab rege peterent, ne inimicissimum suum (patrum) secum (rege) baberet sibique (patribus) dederet. 25, 22, 2 cum Agrippa [Atticnm] obsecraret...... se (Att.) sibi (Agrip.) suisque (Att.) reservaret.-Jug. 81, 3 Iugurtha ratus, si dux Romanus auxilio suis venisset, proelio sese certaturos 
(where suus refer's to dux and sese to Iugurtha and Bocchus, as the context shows). 112,1 rex legatum appellat dicitque sibi (regi) cognitum posse bellum poni; quamobrem regis sui (legati) sententiam exquireret.-Liv. 1, 13, 2 mulieres hinc patres, hinc viros orantes, ne se (patr. and vir.) sanguine respergerent; ne parricidio macula:cnt partus suos (mul.). 2, 6, 3 [Tarquinius dixit alios] inter se (nl.) partes regni rapuisse; bona sua (Tarq.) populo dedisse...... patriam se (Tarq.) regnumque suum (Tarq.) repetere...... [Veientes] suas (V.) iniurias ultum irent. $24,31,8-9$ [Syracusani consuli scripserunt]......nec umquam Syracusas quieturas, donec quicquam externorum auxiliorum in exercitu suo (Syrac.) esset; itaque daret operam, ut cos, qui cum suis (Syrac.) praetoribus castra haberent, in suam (consulis) potestatem redigeret. $32,2,6$ Narnensium legatis querentibns ad numerum sibi (Narn.) colonos non esse et immixtos quosdam non sui (Narn.) generis pro colonis se (quosdam) gerere. 36 , 25, 6 rex baud dubius, quin, si prius Heraclea capta foret, Romanis se (to sbj. of dedituri essent) potius quam sibi (regi) dedituri essent suamque (cons.) gratiam consul facturus esset. Cf. further Liv. 1, 50, 6 se, suam ; 26, 29, 4 suo, se, se ; 35, 6,1 suae, se ; $37,17,5$ sibi, sibi ; 40, 23, 7-8 secum, suorum, sese.-Curtius 8, 1, 9 [ab Alexandro] Scythae petebant, ut regis sui (Scyth.) filiam matrimonio sibi (Alex.) iungeret; si dedignaretur affinitatem, principes Macedonum cum primoribus stae (Scyth.) gentis conubio coire pateretur.

E. The Reflexive in the Speeches of Ambassadors and Messengers.

When the speeches of Ambassadors or other Messengers are reported in the Indirect form, the Reflexive may refer not to the Speakers-the Ambassadors themselves, - - but to the people by whom they are sent and in whose name they speak. This is quite natural, since the spokesman, or messenger, is hinself one of the nation or people for whom he spcaks and in his address can employ the first person plural (nos, noster), which in the Oratio Obliqua report regularly becomes the third person Reflexive (se, suus):-B. G. 1, 13, 6 Divico 
(legationis princeps) dixit: in eam partem ituros Helvetios, ubi eos Caesar constituisset. ..... . se ita a patribus suis didicisse, ut magis virtute quam dolo contenderent (where Divico first calls his people by name, Ilelvetios, but later includes himself by using se, suis-direct form (nos), nostris).-Liv. 31, 14, 3 Atheniensium legati orantes, ut se (=Athenienses = nos) obsidione eximeret. $31,5,5$ Atheniensium nova legatio venit, quae regem appropinquare finibus suis $(=$ Ath. $=$ nostris) nuntincet. 32, 1,9 legati ab Ardea questi in senatu erant, sibi ( $=$ Ardeatibus $=$ nobis $)$ carnem datam non esse. 22, 37, 1-4 (ab Hierone) legati nuntiarunt caedem C. Flumini aegre tulisse regem Hicronem; itaque se (Hieronem) omnia misisse, etc. Here the introduction of se is casy on account of the mention of Hiero by name in a preceding clause.

Sometimes two Reflexives are used, one referring to the ambassador, the other to his nation:-Liv. 24, 33, 5 Romanus orator non bellum se ( = Rom. orat. = ego) Syracusanis, sed opem afferre ait eis, qui perfugerint ad se (= Romanos = nos) 32, 33, 9-16 Princeps Aetolorum Alcxander iam dudum se $(=$ Alex. $=$ ego $)$ reticere ait..... [Philippum] suae $(=$ Aetol. $=$ nostrue $)$ dicionis urbem funditus evertisse. $40,47,4$ (legati Celtiberorum) petierunt, ut sibi in castra Celtiberorum ire liceret ad auxilia accienda; si non impetrassent, tum separatim ab illis se consulturos (where sibi refers to the envoys and se to their people, the inhabitants of the city Certima).

On the other hand, if it is desired to distinguish between the envoy and the sender, the latter may be referred to by name, by a Demonstrative, or by a distinctive ipse:B. G. 1, 13, 3 (Divico) cum Caesare egit: si pacem populus Romanus cum Helvetiis faceret, in eam partem ituros Ilelvetios, ubi eos Caesar constituisset.-Jug. 102, 2 legati a Boccho veniunt, qui ab Mario petivere, duos ad eum (=Bocchum, the Log. Subj.) mitteret.-Nep. 23, 7, 2 legati Carthaginienses (=Carthaginiensium) Romam venerunt, qui senatui populoque Romano gratias agerent, quod cum is (Carthaginiensibus, who sent the embassy) pacem fecissent, simulque peterent, ut obsides eorum (Carthag.) Fregellis essent.-Liv. 
32, 33, 8 praetor Aetolorum Phaeneas cum eadem fere postulasset redderenturque Actolis urbes, quae dicionis eorum, fuissent. $41,19,5$ simul venerant et ab rege Perseo oratores, qui purgarent, nec accitos ab eo Bastarnas nec auctore eo quicquam facere. $45,13,5$ Ptolemaei legati communi nomine regis et Cleopatrae gratias egerunt: plus eos senatui populoque Romano quam parentibus suis debere (where eos $=$ Ptol. and Clcop., and such refers regularly to eos, the subject of the clause in which it stands). 41, 17, 3 (a Ti. Sempronio) legati missi, qui peterent, ut ob eas res, ductu auspicioque $T i$. Semproni prospere gestas, dis honos haberetur, ipsique exercitum secum deportare liceret. In these sentences the Envoys are not permitted, as it were, to speak for the Sender, the writer reporting their speeches from his own standpoint and using the Demonstrative as the regular pronoun of Objective reference. Examples have been eited at some length for the reason that many presumable cases of the use of the Demonstrative for the Reflexive are probably justified by this rule. Thus, for instance, B. G. 1, 11, 3 (Aedui legatos ad Caesarem mittunt: Ita se meritos esse, ut liberi corum in servitutem abduci non debuerint) it is probable that eorum is used to refer distinctively to Aedui, exclusive of the envoys, though se may be inclusive. Cf. Liv. $42,25,8$ legati [who had been sent by the Romans] rettulerunt: regem inclementer locutum, querentem, quod alii super alios legati venirent, quod se ad nutum imperiumque corum (i. e., the Romans) omnia facere aequum cerserent (subject is legati). Cf. also Cic. Verr. 4, 39, 84 eos referring not to the Envoys, but to all the Tyrditoni; Div. in Caec. 1, 2 corum referring perbaps to amnes Siculi, not to the Envoys nor the many (cuncti) districts they speak for in particular.

F. The Reflexive with the Infinitive, Gerund and Participle.

It should be noted that, while, as a rule, in Latin the Infinitive, the Gerund, and the Participle are treated as parts or elements of the clauses in which they may stand, yet very frequently they are looked upon as themselves Abridged Propositions, and pronominal reference by se (Subjective) and by is 
(Objective) must be interpreted and explained accordingly. In particular, though the Acc. \& Infin. construction after volo, inbeo, cogo, etc., is not Oratio Obliqua proper, yet pronominal reference here is the same as in the Acc. \& Inf. after dico, the Reflexive referring either (1) to the subject of the Leading verb, or (2) to the Accusative, the subject of its own clause :(1) B. G. 4, 2, 6 vinum ad se omnino importari non sinunt. 5, 38, 1 peditatumque sese subsequi iubet.-B. C. 1, 4, 4 quod neminem dignitate secum exaequari volebat.-Cat. 46,2 vocari ad sese iubet Lentulum.-(2) B. G. 1, 28, 3 Helvetios in suos fines reverti iussit. -B. C. $1,46,1$ reliquos sese convertere cogunt._Liv. 3, 19, 8 Latinos ne pro se quidem ipsis attingere arma passi sumus. 4, 34, 5 iusso magistro equitum abdicare se magistratu. 27, 3,2 (milites) sibimet ipsos tecta coegerat aedificare.

As regards the Germad and the Participle (especially the Ablative Absolute) no precise rule can be given as to when the Verbals shall be considered as Abridged Propositions. It may be observed, however, that reference to the leading subject by se oecurs (particularly with Abl. Abs.) when the action of the Participle is attributed to the grammatical subject of the sentence, and by is (ille) only when the Participle expresses an action entirely independent of that subject. In the latter case the Logical subject is the Noun modified by the Purticiple, and the Grammatical subjest from that standpoint is viewed Objectively. In a great many instances either the Reflexive or the Demonstrative may be used according to the standpoint the Reporter or Speaker wishes to assume. Examples are given first of the Reflexive referring to the Grammatical subject of the sentence, or clause, in which the Gerund or the Participle occurs :-Gerund.-(O. R.) B. G. 7, 43, 2 legatos sui purgandi gratia mittunt.-B. C. $1,29,1$ Pompeius (sc. Caesari) facultatem insequendi sui ademernt.(O. O. and allied clauses) B. G. 1, 44, 3 Ariovistus dixit: omnes Galliae ciritates ad se oppugnandum venisse; $\$ 10$ debere se suspicari, Caesarem exercitum sui (to Subj. of Gorerning Verb) opprimendi causa habere. 4, 34, 5 barbari praedicaverunt, quanta sui liberandi facultas daretur.-Jug. 
35,9 veritus, ne reliquos populares metus invaderet parendi sibi. Cf. Nep. 10, 4, 1 verens, ne aliquam occasionem sui daret opprimendi.-Nep. 23, 7, 6 Hos Hannibal ratus sui exposcendi gratia missos. Cf. $25,2,2$ idoneum tempus ratus studis obsequendi suis.-Liv. $27,47,11$ (O. R.) spatium dedit ad insequendum sese hosti. $36,16,10$ ut haberent copias ad opem propinquis ferendam civitatibus suis.-Suet. Tib. 40 potestatemque omnibus adeundi sui fecit. Participle.-B. G. 1, 5, 4 Boios receptos ad se socios sibi adsciscunt.-Nep. 14, 4, 5 quem Aspis conspiciens ad se ferentem pertimescit.Liv. 2, 1, 2 quas novas ipsi sedes ab se auctae multitudinis addiderunt. 3, 5, 9 ad signum a se editum eruptione facta, magnam vim hostium circumvenit. 3, 63, 1 vadunt igitur in proelium ab sua parte omissum. 5, 41,9 Papirius dicitur Gallo barbam suam permulcenti iram movisse. 23, 36, 8 (Gracchus) verecundia deserendi socios implorantes fidem suam, etc. $40,32,8$ Acilius manere in captis ab se castris iussus.Suet. Cal. 1 Germanicus legiones sibi summam rei publicae deferentes compescuit.-In the Ablative Absolute:-Cic. Verr. 5, 25, 64 iste quasi praeda sibi advecta, etc. Ad Att. 10,4, 4 quis potest deserta per se patria beatus esse?--B. G. 1, 47,6 Ariovistus exercito suo praesente conclamavit. $3,8,5$ ora maritima ad suam sententiam perducta, legationem mittunt. Nep. 11, 3, 3 Iphicrates vixit ad senectutem, placatis in se suorum civium animis.-Liv. 4, 39, 9 quibus poterat suuciis ductis secum. 9, 40,20 legationibus prae se Romam missis. 31, 16, 2 (Philippus), quodam ex praefectis suis misso, pergit. $33,19,2$ undique se suosque exigente fortuna, urgebatur.-Of course also in O. O. and allicd constructions:-B. G. 1, 40,2 (Cacsar dixit): Ariovistum se consule populi Romani amicitiam appetisse. 1, 8, 2 quo facilius, si se invito transire conarentur, prohibere possit. Cf. $7,6,3$ se invito. In these three examples se refers to the subject of the Governing verb. In B. G. $1,5,4$ suis refers to the subject of the clause of which the Abl. Abs. is a part: Persuadent Rauracis, etc....uti oppidis suis exustis proficiscantur.-Liv. 21, 45, 9 omnes, velut diis auctoribus in spem suam quisque acceptis, proelium poscunt. $45,5,10$ metuens, ne, tamquam a se subtracto poenae reo, iram in se converteret. 
But in very many instances, the Gerund or the Participle and the Substuntive on which they depend or which they modify are felt as Subordinate clauses, and the Reflexive, in consequence, refers not to the Grammatical subject of the sentence, or clatuse, but to the Logionl subject-the Substantive modified by the Gerund or the Participle.

Gerund (attructed or unattracted) oftenest in expressions like "alicui facultatem (copiam, etc.) dare sui recipiendi (colligendi, etc.)":-B. G. $3,4,4$ ne saucio quidem sui recipiendi facultas dabatur. Cf. $8,16,2$ sui recipiendi. $3,6,1$ neque sui colligendi hostibus facultatem relinquant. Cf. 5, 17, 4 and $7,80,8$ sui colligendi ; 3, 19, 1 ad se colligendos.-B. C. $1,5,1$ nec tribunis plebis sui periculi deprecandi facultas tribuitur.-Nep. 5, 4, 4 sic se gerendo, minime est admirandum, si et vita eius fuit secura et mors acerba. [Here sic se gerendo = cum sic se gereret; but the sentence begins as if Cimon, not vita cius wore the subject.]-Liv. 10, 28, 11 Gallica acies nullum (sc. eis) spatium recipiendi se dedit. $10,36,18$ dominis ad res suas noscendas recipiendasque revocatis. $32,13,6$ rerum starum ferendarum sccum dominis eius fiebut. $40,8,13$ mos sibi cuique rapiendi tyrannidem exortus sit. 30, 34, 10 principum quoque signa fluctuari coeperant, vagam ante se cernendo aciem. [Here ante se cernendo $=$ cum ante se principes cernerent. Cf. above, Nep. 5, 4, 4.]-Val. Max. 5, 9, 1 defendendi se adulescenti potestatem fecit.

Participle:-Cic. Acad. 2, 37, 118 Plato ex materia in se omnia recipiente mundum esse factum censet.-B. G. 5, 36, 1 cum Ambiorigem suos cohortantem conspexisset (cf. Liv. 26, 39, 16 Quinctium hortantem suos hasta tranfigit). B. G. $7,20,12$ quem se ex fuga recipientem ne qua civitas recipiat, provisum est.-B. C. $3,46,2$ ut praesidio nostris se recipientibus essent (se may of course refer to nostris used as a Noun in 3rd Person ; cf. B. C. 3, 46, 6).-Jug. 62, 1 is Ingurtham miscrantem fortunas suas accedit.-Nep. 22, 2, 1 (Hamilcar) multo aliter ac speraret rem publicam se habentem cognovit. [After these verbs of Perception and Conception, the Participle and the Accusative it defines form, in effect, an $\mathrm{O}$. O. construc- 
tion.]-Liv. 10, 14, 15 integrae vires sistunt invehentem se iam Samnitem (cf. 31, 35, 3 invehentem se hostem). 31, 40, 8 Dardanos recipientes sese (cf. 31, 43, 1 Dardanos recipientes se). 35, 30, 9 delectos, nibil praeter gladios secum ferentes. $36,11,2$ patrem invitum se gravioris fortunae condicioni illigantem. 29, 3, 2 dedentibus sese responsum est. Cf. 23, 44, 2 dedituris se; and 36, 10, 3 dedentium sese-both in 0 . O.-(Ablative Absolute) Nep. 25, 16, 4 non enim Cicero ea solum, quae vivo se acciderunt, futura praedixit, sed etiam, etc. (where vivo se, if considered as forming a clause, may have the Reflexive of subjective reference, although the Relative here has the Indicative).-Liv. 7, 37, 13 pluribus hostium in tentoriis suis quam in portis valloque caesis. $9,14,1$ parantibus utrisque sc ad proelium legati interveniunt. 22, 60, 9 plerisque regressis in castra sua. 32, 14, 8 Amynandro cum suis auxiliis accito. $37,44,5$ pluribus congregantibus se. $38,17,13$ natura vertente se.

On such an Ablative Absolnte may depend an O. O. or kindred subordinate clause baving a Refiexive referring to the Noun in the Ablative as its Logical leading subject.-Livy 21, 8, \& Poeno cepisse iam se urbem credente-nec ullo pedem referente, ne in relictum a se locum hostem inmitteret (where se refer's to P'oeno and $a$ se to ullo, also subject of immitteret). A like reference obtains with Adjectives:-Cic. in Cat. 4, 9, 19 habetis ducem oblitum sui.-Jug. 9, 3 En habes virum dignum to atque avo suo, Masinissa. 70, 2 Bomilcar socium sibi adiungit Nabdalsam, carum acceptumque popularibus suis (i. e., Nabdalsae).-Liv. 8, 35, 1 (tribunos) suam iam vicem magis anxios, etc. $25,18,2$ ingens ferocia superbae suopte ingenio genti crevit. $4 \%, 16,6$ compotem iam sui regem amici deferunt ad navem. 9, 37, 9 alios semisomnos in cubilibus suis caedes oppressit. Cf. 25, 38, 17 in cubilibus suis oppressos; and 5, 45,3 cubilibus suis excitos-the same use with a participle. In vearly all these passages, however, suus may mean lis, their, its onon.

With Substantives:-Cic. de Fin. 5, 13 conservatio sui.B. C. 1, 4, 3 Scipionem spes impellit, simul adulatio atque ostentatio sui.-Liv. 5, 45, 6 miseratio sui-thus frequently 
and in all periods of the language. At Cat. 28, 1 introire ad Ciceronem ac de improviso domi suae imparatum confoderewe may consider the Substantive domi as equivalent to a clause $=$ cum domi esset, there being no present participle of esse, or we may take sui $=$ his own. Cf. Cic. in Cat. $1,13,32$ desinant insidiari domi suac consuli.

The preceding citations show the reference of the Reflexive (1) to the Grammatical subject of the sentence, (2) to the Logical subject of what is an abridged clause, and (3) in oblique and semi-oblique constructions to the subject of a Leading Verb. Now, it sometimes happens, and especially in Livy, that when these Verbals are considered as forming themselves Subordinate clauses, reference to the Grammatical subject of the sentence can be made (oftenest in the Abl. Abs. construction) by the Demonstrative $i s$, sometimes ille. On this ground can best be explained the presence of a Demonstrative in such sentences as follow :-Cic. Verx. 1, 22, 59 eius; Brut. 61, 220 vivis eins aequalibus. -B. G. 1, 14, 3 Caesar respondit: num etiam recentium iniuriarum, quod eo invito iter temptassent ......memoriam deponere posse? (where we should expeet $s e=0$. R. me; but the Abl. Abs. is felt as a clause dependent on quod......temptassent, and reference to Caesar from the standpoint of the subject of temptrssent is Objective).B. C. 1, 2, 3 Scipio dixerat: timere Caesarem creptis ab eo duabus legionibus, ne ad eius periculum retinere eas Pompeius videretur. Here, again, we look for se, but Pompey is the anthor of the action expressed in the Participle and, besides, it is Scipio that is speaking; nor is the ne-clause expressed from Cacsar's standpoint-whence eins. It is interesting to compare B. C. 1, 9, 4, where Caesar himself is speaking of this same fact and from his own standpoint-whence se: retineri legiones duas, qune ab se sint abductne.-Jug. 62, 1 Bomilcar dixit : caveat, ne illo cunctante Numidae sibi consulant. Here the $A b l$. Abs. = a dum-clause dependent on consulant and from standpoint of Numidae; besides illo represents the 2nd person of O. R. Cf. Liv. 31, 3, 6 ne iis cunctantibus; and Nep. 4, 4, 6 meritum de illo (= te).-Livy 38,14 , 8 veniendique ad eum tyranno potestatem et copiam purgandi se faceret 
(where the Reflex. se refers to its Log. subj. tyranno, and the Demonstr. eo to the Grammat. subj.). 45, 44, 16 donec ad classem dono datam ei rex pervenisset (where ei refer's to rex; but datam ei = quae ci data erat, an Indicative explanatory clause in O. O.). $31,42,8$ Athamanes (Accus.) itincrum periti per calles ignotas seçnentibus eos hostibus in Aetoliam perduxerunt. Here the Dative sequentibus hostibns $=\mathbf{a}$ siclause not in $O$. $O$. and from the standpoint of the Writer. 22, 49, 2 aliquot locis proelium restituit, protegentibus eum equitibus Romanis. Here eum refers to the subject of restituit; but the Abl. Abs. follows the leading clause and, being entircly detached, forms a clause of its own. Similar are: Liv. $23,8,7$ (filins) ipse valetudinem excusans, patre animi quoque eius ( $=$ filii) hand mirabilem perturbationem causante; and 24, 3, 9 arce optimates tenebant se circumsedente cos (= optimates) etiam plebe sua ( $=$ their own).

\section{G. The Reflexive Where the Demonstrative Might Be Expected or Used.}

Finally, the Reflexive is found in a large number of passages where the Demonstrative is looked for and might properly stand; but in almost no instance do se, suus occur where their use cannot be explained by the rules already given for their reference. When the Retlexive stands in a clause in which at first view we should look for the Demonstrative, it will be seen on closer observation that either it refers to a Logical subject or sucu has the meaning of "own," or that there is in the sentence Subjective statement, O. O. implied or imputed.

(a) Logical Subject. -See pages 9, II. ff., and CH. Tac. II. 5, 5 inter se nihil illicitum. Curt. 5, 6, 6 obvii caedebantur, quos anter pretium sui miserabiles fecerat.

(b) Sunu= his own, proper, etc.:-B. C. 1, 22, 5 Caesar interpellat: Se non maleficii causa cgressum, sed ut tribunos plebis ex civitate expulsos in suam dignitatem restitucret (suam $=$ which rightly belonged to them and bad formerly been their own). Jug. 64, 2 (Metellus Mario dixit): debere illi res suas satis placere (suas = his own; and $i l l i$ is Log. Subj.).Liv. 29, 30, 12 qui Maznetullo suce (= his property) omnia 
restitui sponderent. 37, 25, 12 nisi cum suus primum furor, deinde fraus Aetolorum absumpsisset (suus opposed to Aetolorum). $32,11,4$ ut suae potius omnia quam illius potestatis essent-and in several other passages previously cited. Cf. Cic. ad Fam. 11, 11, 1 ex libellis suis ; ad Att. 6, 2, 7 sua (cum implied).

(c) O. O. plainly implied-as with tamquam, quam si, etc. :-Liv. 7, 20, 1 Caerites, tamquam in verbis hostium vis maior quam in suis factis esset, terror invasit. Cf. $8,3,8$ tamquam de se. $-3,24,9$ quam si lex minuendae suae maicstatis causa promulgata ferretur. Cf. Plaut. Rud. 2, 3, 79 quam si ex se simus natac; and see page 9.-So with quippe ce Participle:-Liv. 3, 63,2 in hostes iam pavidos, quippe fuso suac (=hostium) partis validiore cornu, impetum fecit. In Liv. 7, 32, 2 (cos) in Campanos stimulabat ira, tam promptos ad accersanda adversus se auxilia, - the Reflexive is correct as it refer's to the Log. subject (eos) and promptos = O. O. quod prompti essent.-B. G. 8, 54, 3 Cacsar tamen, cum de voluntate minime dubium esset adversariorum suorum, Pompeio legionem remisit (where the cum-clause expresses Caesar's thoughts. Cf. Nep. 15, 3, 5 where cum . . . captus esset expresses the thought of Epaminondas).

(d) Sometimes we have clauses in which there scems to be a mingling of $O$. O. with the $O$. R., a change of standpoint, and the Pronoun of $\mathrm{O}$. O. with the Mood of O. R. This occurs most frequently in Relative clauses with the Indicative, but also in Causal clauses and other's, where for one reason or another the Indicative is retained. (Relative Clauses): - Jug. 61,1 Metellus in eis urbibus, quae ad se defecerant, praesidia imponit. 66, 1 Iugurtha civitates, quae ab se defeccrant, formidine aut ostentando praemia affectare. 88, 4 statuit urbes, quae viris aut loco pro hostibus et advorsum se opportunissumae erant, singulos circumvenire. 103, 2 Bocchus, seu reputando quac sibi duobus proeliis venerant, seu, etc.-Bell. Afr. S qui cum eo bellum contra se gerebant.-Nep. 14, 6, 8 quod ad perniciem suam fuerat cogitatum, id ad salutem convertit. $25,7,1$ quae amicis suis opus fuerant, omnia dedit. $15,8,3$ quos ante se imperatorem nemo Boeotorum ausus 
fuit aspicere in acie (but the text is doubtful. Halm emends ausus sit; Riemann, ausus fuisset).-Liv. 8, 35, 1 stupentis tribunos et suam iam vicem magis anxios quam eius, cui anxilium ad se petebatur. 24, 33, 6 eis, qui ad se perfugerunt (where various editor's emend to perfugerint, against the mss.). 25, 6, 12 Caudinae legiones hostem sub iugum miserint, qui hac sua ignominia laetatus fuerat. 27, 51, 13 Lucanorum, qui snac dicionis erant, in Bruttium agrum traduxit. $37,25,4$ Antiochus non civitatium modo, quae circa se orant (=quas habebat), contruhebat pracsidia (where Madvig strikes out se, though he lets it stand in 7, 37, 3 centum boves militibus dono dedit, qui secum in expeditione fuerant (=quos habuerat)). - Liv. 2, 43, 6 quantum in se fuit (= quantum in se positum habuit or per se potuit). (Cf. Nep. 11, 3, 4 quantum in se fuit ; but Cicero pro Flacc. 25,61 has "quantum in ipsis fuit."-Curt. 5, 5, 6 obvii caedebantur, quos anter pretium sui miserabiles fecerat. - Vell. 2, 56, 1 Caesar omnibus, qui contra se arma tulerint, ignovit (Cf. B. G. 6, 9, 2 contra se).- Suet. Caes. 34 quae sibi portas clauserat. $7 \pm$ qui necem suam inimicis promiserat. - (In other clanses) B. C. 3, 53, 5 quem Caesar, ut erat de se meritus ab octavis ordinibus ad primipilum se traducere pronuntiavit.-Nep. 25, 12, 3 cum L. Saufeii, aequalis sui, triumviri bona vendidissent, Attici labore factum est, ut, etc. (where the cum-clause gives the motive of the Log. subj. Lttici).-Liv. 1, 17, 2 ne, quia post Tatii mortem ab sua parte non erat regnatum, possessionem imperii amitterent. (Cf. 28, 8, $1 \pm$ ab se.) 2, 55, 6 Volero, ubi indignantium pro se acerrimus erat clamor, eo se in turbam recipit (i. e., where he saw that, etc. ; but the Subjunctive would give a different meaning). 26, 3s, 1 Hannibalem angebat, quod Capua pertinacius oppugnata ab Romanis quam defensa ab se multorum animos averterat. Here the fact is vouched for by Livy (averterat) and at the same time stated as the thought of Hannibal, logically subject, by the use of se. In 39, 23, 6 una eum res maxime angebat, quod, qui abse defecerant, in eos ius saevendi ademptum $e i$ ab senatu eratLivy writes $a b$ se imputing the thought of the qui-clause to Philip; but with immediate change of standpoint writes 
Objectively ei, thus stating the quod-clause as an independent fact.-In Nep. 1t, 7, 3 locum deligit talem, ut .... non multum obesse multitudo hostium suae paucitati posset-suae is perfectly regular, as the clause is Final. Non attaches itself to multum and talem does not demand ut-Consecutive.

(c) In the following, where an apparently irregular suus of $O$. R. is found, it is easy to conceive of the clause as abridged O. O., with iubeo or similar verb implied. Thus B. G. 5, 53, 3 Caesar Fabium cum sua legione remittit in hiberna (= Cacsar Fabium cum sua legione ire iussit).-B. C. 3, 97, 3 partemque legionum in castris Pompei remanere iussit, partem in sua castra remisit (where we have iussit in the first clause, which might have been followed by redire; but suci may also mean "their own," opposed to Pompei). Cat. 21, 4 admonebat alium egestatis, alium cupiditatis suae (= iubebat alium menorem esse cupiditatis snue. Cf. Tac. Ann. 1, 12 Tiberiumque ipsum victoriarum suarum admonuit).-Tac. H. 1, 64 cohortem duodevicensimam Lugduni, solitis sibi hibernis, relinqui placuit ( $=$ iussit). More difficult to explain are these two from Nepos: 1, 1, 1 Miltiades, cum en esset aetate, ut non iam solum de $e o$ bene sperare, sed etiam confidere cives possent sui talem eum futurum, etc. The $u t$ is plainly Consecutive; sui here can hardly mean his own, as it is apparently unemphatic ; nor can Miltiades be taken as Log. subj. of possent, as we have de eo immediately before.-17, 7, 4 domo eadem fuit contentus, qua Eurysthenes, progenitor maiorum suorum, fucrat usus. It is barely possible that Nepos imputes here to Agesilaus a motive for not quitting this house: "It was the house of my ancestors." It is a well-known fact, however, that Nepos uses very often an unemphatic suns, and especially in certain expressions (as, cives sui, copiae suae) inserts the Possessive where other writers would omit it, even when its reference would be regular. See, for example, Nep. $1,3,5$; $1,7,4 ; 1,8,1 ; 2,8,1 ; 6,4,1 ; 9,2,1 ; 9,4,5 ; 20,1$, $3 ; 23,1,2$ (cives) $1,4,2 ; 1,5,4 ; 5,2,3 ; 17,3,1$ and very many others. 
The Demonstrative.

As the Reflexive is the Pronoun of Subjective, so the Demonstratives are Pronouns of Objective, Reference. In the Simple Sentence the Demonstrative is, therefore, used to refer to a word not the subject; and in all Subordinate clauses not expressing the thought of the subject of the Leading clause is or ille may refer to the subject of this Leading clause. This is the rule in Indicative Dependent clauses, and in some Subjunctive clatuses, as Conditional, Concessive, Temporal, often with clauses introduced by quin, quominus, and notably in Consecutive clauses. Such use of the Demonstrative, as being out of the sphere of Indirect Discourse, does not concern us here. It may be said that, in general, the use of is is the same in $O$. O. as in O. R., the sphere of its reference, however, being greatly extended. Since this is so, only those uses that are peculiar or irregular require discussion here.

As the conception of the $O$. O. period is, from the standpoint of the Speaker, regularly Subjective, so from the standpoint of the Reporter it is Objective, and reference to the Leading Subject is made Objectively by the Demonstrative. Although (as has been shown at length) the Reporter usually assumes the strndpoint of the Speaker whose words or thought he is quoting and allows him, as it were, to make his own statement indirectly, yet it often happens that, instead of using this Subjective statement and consequent Reflexive reference, the Reporter presents the words or thought of the Speaker Objectively and employs for reference to the Speaker the Demonstrative-usually is, sometimes ille. As in the case of the Reflexive in Indicative clauses there is an evident mingling of O. O. and O. R. (the Mood of O. R. and the Pronoun of O. O.), so with this reference of the Demonstrative there is a similar two-fold conception, where the Latin has the Mood of Subjective and the Pronoun of Objective reference. There are frequently very evident reasons for this change of standpoint and employment of $i s$, where the Reflexive might be expected. Sometimes the writer chooses to state as an historical fact, objectively, what is evidently the word, thought, or motive of the Leading subject; sometimes he aims at greater exactness 
and desires to avoid all ambiguity, especially in a series of dependencies with changes of Subject. This use of the Demonstrative is found most frequently in Subjunctive clauses of the O. O., less often in the Acc. \& Inf. construction, and always after the introduction of a new Subject. Most of the examples occur in Livy and Caesar. Nepos has sereral, Cicero fewer comparatively, and Tacitus remarkably few irregular uses of the Pronouns, considering the various peculiarities of his style and diction. But examples are found in practically all authors and in every period of the language. An examination of the passages one by one will nearly always show the reason in each particular case for the employment of is. In only a few instances does the use of the Demonstrative seem entirely unnatural. In such cases, where we should certainly expect the Reflexive, the anthor may have been guilty of a negligence of expression. But, generally speaking, it is unwise to attempt an exact statement of the limits of such Objective reference, and a critical study of the use of these Pronouns in the best Latin writers will convince one of the folly of speaking dogmatically on the subject.

Reference, then, to a Leading subject may be made by the Demonstrative instead of the Reflexive, when the Writer does not wish to present the Subordinate clause as the thonght of that subject. In the following passiges is is perfectly natural, thrugh se, suzs might have been used, giving a different conception :-B. G. 6, 10, 1 fit ab Ubiis certior Suebos iis nationibus, quae sub eorum sint imperio, denuntiare, ut, ctc. (the Relative clause is the statement of Uhii; the Reflexive would change the meaning entirely). $1,18,8$ reperit Dumnorigem odisse Caesarem et Romanos, quod corum adventu potentia eins (Dum.) deminuta sit (statement of the Writer, and the quod-clnuse would be Indicative but for the O. O. Cf. 1, 31,10 quod ad cum venissent; and Liv. 45, 13, 14 quod rogasset eum senatus; quod pecuniam ei misisset). B. G. I, 31, 12 Ariovistum in cos omnia exempla cruciatusque edere, si qua res non ad voluntatem cins (Ariov.) facta sit (the thought in si-clause not attributed to Ariovistus). 4, 11, 5 Caesar dixit : quam frequentissimi convenirent, ut de eorum postulatis. 
cognosceret. Cf. Liv. 42, 26, 5 quaesitum est, quid ita non adissent magistratum, ut scirctur denique, venisse cos. In both these sentences the ut-clauses are Final, but the purpose is rather that of the speakers (Cacsar and those who inquired) than of the persons addressed. - Similar are: Liv. S, S, 18 Romano permissum crat ab consulibus, ut succenturionem sibi legeret, cui tutaretur eum (purpose of the consuls). 21, 59, 10 venienti in Ligures Hannibali quaestores, quo magis ratam fore cum iis pacem crederet, traduntur ( $\ddot{i}$ s from standpoint of $F_{\text {. }}$, rather than secum, from standpoint of Ligures). $\pm 5, \pm$, 6, allerac litterae [a Perseo] et peticre et impetrarere, ut aliqui ad enm mitterentur (where, though Perseus is Log. Subj., the letter is personitied and speaks of him Objectiraly). -Tac. H. 5, 9 iussi a Gaio Caesare efligiem eius in templo locare arma potius sumpsere (eius Objective, where we might have had suctm from the standpoint of the Log. Subj. of the Participle, Cacsare). In Cic. de Oft. 1, 33, 121 pracstare debebit iustitiam..... quo minus $a b$ co id, quod desit, requiratur-quo is Final, but os Objective from standpoint of Cicero or from that of Log. Subj. in requiratur.

In the following Final clauses the Demonstrative appears less natural :-Cic. de Oft. 1, 30, $10 \mathrm{~s}$ callidum factum Solonis, qui, quo tutior vita cius esset, furere se simulavit. (Here the idea of Result also may be present, and Cicero is speaking rather of the "shrewd trick that sweved Solon's life.") Cf. a similar use of 2 is in B. C. 3, 30, 5 ignesque fieri prohibuit, quo occultior esset cius adventus. B. G. 6, 29,5 (Caesar Iucium) monet, ut ignes ficri prohibeat, ne qua cius adventus procul significatio fiat (where, however, eirs condnces to elenrness). S, 42, 4 ita quisque, quo notior testatiorque virtus esset eius, telis hostium se offerebat.-Tac. Amn. \pm , 67 Cacsar, quamquam edicto monuisset, ne quis quietem eius irrumperet (Objective from standpoint of Tacitus, or as quoting the entict). Tac. H. 2, 9 (Nero), ut eum in Syria aut Acgypto sisterent, orabat (milites).

Differing somewhat from these are the following :--B. G. 1, 5,4 Perstradent Raurncis . . uti una cum is proficiscantur (cf. 1, 6, 3 eos). 1, 35, 3 Cacsar legatos cum his mandatis 
mittit: Sequanis (Arioristus) permitteret, ut quos illi haberent, voluntate eius (Arior.) reddere illis liceret (eius, because of the introduction of a Brd Subject illi). 2, 1, 2 coniurandi has esse causas: primum, ruod vererentur, ne ad eos exercitus noster addnecretur (eos from standpoint of Writer, or of exer-f citus the new subject). $2,14,5$ Divitiacts fecit verba: petere non solum Belloricos, sed etian pro his Aeduos, ut sua clementia in $\cos$ (Bellov.) ntatur (where as is correct, as the clause is construed from standpoint of Aeduos). [Here may belong also B. G. 1, 11, 3, if not at pange 21; and 1, 1t, 3, if not at page 26. For B. C. $1,2,3$ ab eo, eius, see prge $2(4$ and ct. 2, 1, 2 above. For Jug. 62, 1 illo, see also pang 26.]Nep. 2, $8,3 \mathrm{cum}$ principes animadrertisset timere, no propter se bellam is Laceducmonii et Athenienses indicerent (where, se having been used to refer to subject of animaleertisset, Nepos uses iis to refer Objectirely to the suhj. of timene; yet siti would certainly not culse ambiguity, althongh there aro three difierent subjects in the passage). Similar is Nep. 23 , 9, \pm inseientibus iis.-Lix. 32, 8, 11 Attalun orno patres conscriptos, ut, si sua (Att.) classi suaque opera uti rellent, mitterent ipsi prasidium ad regurm eius (Att.) butmilum; si id nollent, ipsum ad sua (Att.) defendenda redire paterentur. Here the first reference is by sua, regularly; the Distinctive ijss bas the eifect of transferring the point of view to patres, whence eius. Later ipsum again reverses the standpoint.Liv. $42,33,3$ pro conturionibus M. Popilius ita verba fecit: (cos) id tantum deprecari, ne inferiores $i 2$ ordines attribuerentur (iin, becruse Popilius is reporting to the people the request of the centurions). Cf. $5,2,5$ eorum.

The use of the Demonstrative in the following Relative clauses should be noted :-B. G. 1, 47, 1 Ariovistus ad Caesarem legatos mittit : velle se de his rebus; quac inter eos $(=0$. R. nos) agi cocptac essent, agere cum eo (eos is grammatically clearer than se would be).-B. C. $1,85, \frac{1}{2}$ (Milssilienses dicunt) : principes esse earum partium Cn. Pompeium et C. Cacsarem, quorum alter agros Volonrum, etc. ... iis (Massil.) concesserit.-Liv. $41,19,6$ moneri eum iussit, ut cururet, at sanctum babere foedus, quod ei $(=0$. R. tibi) cum Romanis csset, videri pos- 
sct. 42,62, 5 mitteret ad consulem, qui foedus in easdem leges renovarent, quibus Philippus pater eius $(=0 . R$. tuus) pacem accepisset.-In all these clanses the Reflexive conld bave been used with a slightly different fecling.

The same use occurs in clatses introduced by various Conjunctions:-[Cutust]] B. G. 5, 27, 2 Ambiorix locutus est: sese pro Cacsaris in se beneficis plurimum ei confiteri debere, quod . . . quodque ei (= Ambiorigi) et filinis et fiatris filius ab Caestre remissi essent. Here we should expect sibi, not ei; for ambiguity is not possible and, besides, the Demonstrutive has been twice used already to refer to Caesar. We have here, then, the Mood of $\mathrm{O}$. O. with the Pronoun of $\mathrm{O}$. R. Although the clause is eridiently a part of the speech of Ambiorix, the Author at the same time gives the reason Objectircly. Cf. B. G. 1, 37, 2 venicbant Acdui questum, quod Harudes fines eortum popularentur. - Liv. 5, $1, \pm-5$ grotvis iam is antea genti (Etruscae) opibus superbiaque, quil sollemnia ladorum diremisset, cum ob iram repulsae, quod sacerdos ei praclattis esset, artifices abduxit (where the context shows that the quol-clause is in the Subjunctive to give the alleged reason of the Etruscons rather than of the Veientan ling). [Conditional] B. G. 2, 17, \pm quo facilius finitimorum equilatum, si praedandi calusa ad eos venissent, impedirent.-Liv. 3, 64, 7 consules interrogati, si cos populus Romanus, memor libertatis per illos recepta domi, consules iterum facerent (eos and illos from standpoint of pop. Rom.). CA. Liv. $7,5,5$ patris eius ; 31 , 11, 12 ci.-Nep. 14, 10, 1 (Mithridates) pollicitus est regi, se cum (Datamen) interfecturum, si ei (Mithrid.) rex permitteret, ctc. (where $c i$ is the Objective statement of Nepos, or perhaps the si-clause may be conceived as representing the promise of the king: $O$. R. "tibi permitto," is regularly replacing the pronoun of 2 nd Pers.). Sibi also conld bave been used. Cf. Cic. de Off. 3, 22, 86 perfugal (Fubricio) est pollicitus, si pracmium sitji proposuisset, se eum (Pyrihum) necaturum. -[prusquam] B. G. 7, 1, i rationem esse habendam dicunt, priusquam eorum clanclestiua consilia effermutur, ut Cacsar intercludatur (se would secm more natural, as priusquam implies puppose $=$ ne prius). See also Nep. 2, 8, 4 inde non 
prius egressus est, quam rex eum in fidcm reciperet. - [ Indifiect Question] Liv. 35, 46, S viderent quid patiendum iis (to Subj. of viderent) extemplo foret.-[Rardy with Acc. \& $I n f$. B. C. 3, 28, 3 tirones perterriti iure iurando accepto, nihil iis (tiron.) nocituros hostes, se Otacilio dediderunt (perhaps $==$ cum hostes iurassent, se nibil iis nocituros). Cf. Liv. $7,5,5$ patris eirk, and Nep. 1, 4, 5 de eorum virtute. In Nep. 17, 3, 4 vidit, hostes non credituros... neque dubitaturos aliud eum facturum-we have eum referring to the Subj. of vidit from the standpoint of hostes, or, as most often is the case, from the standpoint of the Author.

The use of is (ille) from the standpoint of the Reporter or other person than the Subject, seems more strange in these passages:-Cic. Vorr. II, 1, 3t, so Milesios navem poposcit Verres, qua eum (V.) prosequeretur.-Jug. 96, 2 (Sulla) magis id laborare, at illi (Sul.) quam plurimi deberent (but the text is (questionod).-Liv. 1, 5 \pm , 5 (tilius) sciscitatum Romam ad patrem mittit, quidnam se (fil.) facere vellet, quandoquidem, ut omnia unus Gabiis posset, ei (fil.) di dedissent (where the first dependency has, regularly, se, but tho second has ei. Perhaps in the quandoquidem-clause Livy quotes the messenger). 9, 5, 9 (proponere sibimet ipsi ante oculos) reditum in patriam ad parentes, quo snepe ipsi maioresque eorum triumphantes venissent (where ipsi and exrum refer to Subject of proponere (= proponebant); but se, sibi, sili immediately follow referring to the same). $31,3 \pm, 1$ Philippus aliruid et ad caritatem snorum et ut promptius pro eo periculum adirent ratus profecturum se, ete. $32,5,9$ ii regem vereri dixerunt, ne id pracstare ei (regi) ultra non liceret (ei perhaps from standpoint of diremunt). 32, 34, 5 an, quod a sociis eorum non abstinuerim, iustam querelam habent? Cf. 38, 56, 12 castigatum enim quondam ab eo populum ait, quod eum perpetum consulem vellet facere and B. G. 5, 27, 2 cited above. In these three wo have a mingling of the Direct with the Indirect style, with the Mood of O. O. and the Pronomn of $O$. R. The second cxample $(3 \mathrm{~S}, 56,12)$ is the most natural, as ab eo is only a $L o g$. Subj. to castigatum. - At Livy 31, 11, 12 iussique polliceri, si, quid ei opus esse, indicasset, enixe id populum Romanum 
praestaturum-ei refers to the subject of the Subordinate clause from the standpoint of the Senate sending the envoys. Madvig's emendation eis does not seem necessary. For similar reference compare the examples under the Gerund, Participle, etc., pp. $26,27$.

In these two passages from Livy there are especial reasous for the use of the Demonstrative, although the Reflexive would have been more exilet or more according to rule: $1,56,10$ cupido incessit animos iuvenum sciscitandi, ad quem eorum regnum esset venturum (O. R., Partitive Gen. nostrum ; but the corresponding form of the Reflexive does not exist, though, if emphatic, ex ipsis is used; but ef. Val. Max. $\tau, 3,2$ quisnam ex ipsis). - $\pm 1,8,8$ Fregellas millia quattuor familiarum transisse ab se Samnites Paelignique querebantmr, neque co minus hos aut illos in dilectu militum dare (se is first employed regularly; then to refer to the different peoples separately the Demonstratives hos, illos are used. The contrast could hardly be expressed otherwise; and besides it is only Envoys from these nations who are speaking and, as we have seen, they may use the Objective reference to their Senders.

\section{Ipse.}

As in the case of the Reflexive and the Demonstrative, so with the Intensive, Distinctive ipse, the principles underlying the reference and use of the prououn in O. O. are the same as in O. R., except that the sphere of reference is greatly extended. Ifjse is regularly used for Emphasis, Distinction, or Contrast. and may qualify nouns or pronouns of any of the three Persons. As all pronouns in $O$. O., especially in the Fistorians, are usually of one Person-the third, distinction by means of emphasis and contrast is more often necessary than in the direct form, and in consequenee ipse appears more frequently. Since, morcover, the subject of the Governing Verb is usually the principal actor, the most prominent personage in the mind of the writer, ipse naturally and most frequently refers to that subject-distinctively and in contrast to other persons mentioned in the sentence, and particularly when that subject is opposed to the subject of a Subordinate 
Clause. Thus, while the Refictive regularly reproduces the Speaker without emphasis, ipse will be employed not only when it stood in O. R., but ulso whenever in direct style ego or nos would be expressed, if these pronouns should bo in the Nominative. For instance, B. C. 1, 9, 5 ipsi exercitus dimittant-reproduces an O. R. nos dimittamus; and in Liv. 42, 47, 2 apparatibus belli fuisse instructum (regem), ipsis nulla parata re-if the Abl. Abs. be expanded, we should have, O. R., cum nos . . . haberemus.

Following are examples of reference to the strbject of a Governing Verb, which might easily be multiplied :-B. G. 1, 19, 1 quare aut ipse animadverteret aut civitatem animadvertere iuberet (Caesar contrasts what he should do himself with what he shonkl arder done. Cf. 1, 19, 5 vel ipse... vel civitatem; and for the same contrast in $O$. R. see Cat. 55 , 2 tresviros parare iubet, ipse Lentulum deducit). B. G. 1, 20, 2 Divitiacus dixit. . nec quemquam ex eo plus quam se doloris capere, propterea quod, cum ipse gratia plurimum, ille minimum posset, cte. (ego would bo expressed in $O$. $R$. Cf. 1, 20, 4 cum ipse $=$ cgo).-B. C. 1, 11, 1. Erat iniqua condicio (sc. Pompeium) postulure, nt Caesar excederet... ipsum provincias tenere (ipsum, to Pomp., contrasted with Cres.). 3, 16, 5 (dixcrunt) : ithum per se acturum bortantibus ipsis. -Nep. $7,5,1$ pertimucrunt, ne ab ipsis descisceret et cum suis in gratiam rediret (ipsis contrasted with suis). Jag. 16,2 Iugurtha legatos mittit, qui ipsi liberisque vitam peterent (ipsi $=$ O. R. mihi, in distinctive, cmphatic scnsc). Similite expressions occur very frecuently in Livy : $3,3 \pm, 2$ ipsis liberisque corum ; $40,5,1$ ipsum liberoscuc eius; 9,5 , 9 iłsi maioresque cortum; $2,31,3$ ipsi posterisctue $; 1,4,3$ ant ipsam wht stirpem; 1, 26, 12 nec patris nec ipsius; 24 , 31, 12 cum ipsos tum cognatos corum, etc. In B. G. $1, \pm 4,2$ sedes habere in Gallia ab ipsis concessas-ipsis = Gallis, the inhabitants in contrast to their country. Cf. also B. G. 1, 19, 1 inscientibus ipsis-and Liv. 40,8, 12 ipsis (the same use in O. R.).

The rule is frequently given that, when in a Subordinate clause the use of the Reflexive might cause ambiguity, ipose 
should be used to refer to the Subject of the Governing verb, and the Reflexire to refer to the Subject of the Subordinate clanse. This cannot be proved. The Latin autbors rarely took pains to avoid any apparent ambiguity that would result from the $\mathrm{cm}$ ployment of a reticxive, as numerous passages already cited plainly show. When they did, however, strive for absolute clearness or exactness, they either (as has been remurked) used the objective is or ille, or else repented some preceding word or inserted the noun or Proper name for the Pronoum. Always, then, when ipse appenr's to be inserted merely to prevent ambiguity, a close examination of the context will show that it has one or another of its various meanings common in the Direct form. Passages like the following are quoted in justification of this supposed use of ipse:-B. G. 1, 13, 5 ne ob cam rem ant sucue magnopere virtuti tribueret aut ipsos despiceret. In the first place, se for ipsos would not have been ambiguous: and, sccondly, ipsos presents an obvious contrast.-B. G. 1, $\pm 0, \pm$ cur de sucu virtute aut de ipsines diligentia desperarent? Here sua, it is truc, could bardly have been repeated; but, in reality, ipsius, is used to mark a necessary coutrast between the soldiers and their general. Cf. 7, 62, 2 where Labionus uses, in like manner, suae rirtutis and ipsum Caesarem.-B. G. $1, \pm t, S$ quid sibi (Caes.) vellet? cur in sults (Árior.) possessiones veniret? provinciam suam (Ariov.) hanc esse Galliam, sicut illim nostram. Ut ipsi concedi non oporteret, si in nostros fincs impetum faceret, sic item nos esse iniquos, quod in suo (Ariov.) iure se (Ariov.) interpellaremus. In this passage we have the unemplatic Reflexire five times referring to two subjects. A sixtb, sibi, could easily hwe been employed, and ipsi was inserted only for Contrast: at ipsi...... sic item nos. In a word, ipse bas its regular force in these and all similar passiges, and where no Emphasis, Distinction, or Contrist is required the Reflexive is used, no eftort being made to aroid a probable misconception :-Cic. Verr. 2, 25, 60 postaliure inon desistebant, ut se ad leges suas reiiceret. De Off. 1, 28, 99 negligere, quid de se (referring to implied Suljj. of negligere) quisque sentiat, non solum arrogantis est, sed, etc. Cf. 3,14 , 58 ante suos. - At Jug. 22, 4 si ab inre gentinm sese prohibuerit, 
sese is used in spite of the ambiguity, and at B. G. $\tau, 63,5$ (Aedui) contendunt, ut ipsis summa imperii tradatur, ipsis is used where no ambiguity could arise, but because the Aedui are emphasizing their own claims.

Moreover, ipse, instencl of reforring to the subject of the Governing verl), refers often to the subject of a Subordinate clause:-Cic. Verr. 3, 7,18 consulibus scuatus permisit, ut vini et olci decumas renderent legemque his rebus, quam ipsis (to consules, Subj. of edicerent) videretur, edicerent. B. G. T, 5, 5 renuntiant Acdui, se Biturigum perfidiam veritos revertisse, quihus id consilii ruisse cognoverint, ut, si llumen transissent, una cx parte ipsi (_- Bituriges), altera Arverni se (Aeduos) circumsistorent (where the Referive refers to Subject of Governing verb aud ijwi to that of Subord. clatusc).Nep. 2, 7, 6 (Themistocles dixit): Lacedacmonios iniuste facere, qui id potins intuerentur, quod ipsorum dominationi, quam quod universae Gracciae utile esset: quare, si suos (Lac.) legatos recipere vellent, se (Them.) remitterent (where ipssurtem is used merely for contrast, and se, which according to the supposed rule should be ijsum, is used notwithstanding suos). 23, 8, 2 alii a servolis apsine interfectum etum scriptum reli'querunt.-Liv. 6, 36, 11 (Sextius Liciniusque dixerunt) : auderentne postulare, ut, cum bina iugera agri plebi dividerentur, ipsis plus quingenta ingera habere liceret (where ipsis $=$ patriciis in contrast with plebi, the leading subject heing Sext. Licin.).-Or ijese may be used to qualify or reproduce any thind Person of the O. R., an emphatic is or ille:B. G. 1, 1t, 6 Caesar Helretiis respondit: si Aeduis de iniuris, quas ipsis (Aeduis) sociisque eorum intulerint, satisfaciant, sese cum iis (Helretiis) pacem esse facturum. 1, 1.0, 9 Cacsar dixit: hac (ratione) ne ipsum (Arior:) quidem sperare nostros excreitus capi posse. 1, 18, 3 Caesar reperit esse vera; ipsum esse Dumnorigem ("D. was the very man" that had been making trouble).-Tac. Agr. \pm memoria teneo ipsum (= Agric. in person) narrare se hausisse, etc.

Again, ipse is used to reproduce with emphasis or in contrast the Second Person of the O. R. :-B. G. 1, 40, 11 Caesar dixit haec sibi (mibi O. R.) esse curne; de itinere ipsos $(-$ mil- 
ites $=$ ros 0. R.) brevi tempore indicaturos. 4, 11, 6 Caesar ad praefectos mittit qui nuntiarent, ne hostes proelio lacesserent et, si ipsi (vos O. R.) lacesserentur, sustincrent, quoad ipse (ego O. R.) propius accessisset (where we have two instances oi ipse, in one a reference to the 2 nd Pcrs. O. R., in the other a l'eference to the 1st). 5, 27, 9 ipsorum esse consilium, relintne milites ad Ciceronem dedncere, etc. (where Ambiorix uses the Intensive in addressing Titurius and the other envoys). Cf. 5, 36, 2 ipsi (= Titurio) vero nihil nocitum iri, inque eam rem se suam fidem interponere (where the Retlexives refer to the Speaker, Ambiorix, and the Intensive to the person addressed through the interpreter Pompeins).-B. C. 1, 9, 6 Calesar dixit: aut ipse (= Pompeius) propius accedat aut so (- Caesarem) patiatur accedere (where again se reproduces the Speaker and ipse the person addressed).- -Jug. 35, 9 Iugurtha cum Aulo verba facit: tametsi ipsum cum exercitu teperet, tamen se memorem, etc. . . . missurum (here ipsum refers to Aulus and $=0$. R. "you per'sonally and your army"). 108, 2 quem Bocchus ad Sullam nuntiatum mittit : paratum sese (= Bocch.) facere quae populus Romanus vellet; colloquio tempas ipse (= Sulla, O. R. tu) delegeret. - Liv. 32, 8, 11 Attalum orare patres, si sua classi suaque opera uti vellent, mitterent ipsi $(=0$. R. mittite ipsi) pracsidium ad regnum eius (= Att.) tutāndum; si id nollent, ipsum (=O. R. me ipsum) redire paterentur (where ipse is used to refor, first, to the addressed pratres, and, second, to the speaker Attalus, in both instances to murk a contrast. Note that eines is used to refor to the Lereding subject).-In B. C. 1, 9, 5 proticiscatur Pompeius in suas provincias, ipsi exercitus dimittant; ipha reproduces a Direct nos $=$ ego et tu. Cf. $3,10,9$ et rei publicae et ipsis $(=0$. R. mihi et tili) placere oportere, si, ete.

This is different from ipsi $=0$. R. nos, when nos means the Speaker and a Third Person. Sometimes there is such a trinsition in O. O. from the Singular (the Speaker speaking for himself alone) to the Plural (the Spenker speaking for himself and his Party). Of course when the Infinitive has a declinable element the transition is shown at once and the Retlexive is regular and clear. See page 44. But the Reflexive 
se, if used to represent both ego and nos, may be ambiguous when there is nothing in the context to show a change of number. At Tac. H. 4, $1 \pm$ Civilis dicit : tradi se praefectis centurionibusque, the context shows that se is Plural $=0$. $R$. nos. But in similar sentenees the Plural ipsi is found marking the transition. Sce B. G. 1, 43,6 Caesar docebat, quam veteres cuusae necessitudinis ipsis cum Aeduis intercederent (ipsis $=$ nobis $=$ C. et pop. Rom.). Cf. 1, 19, 1 inscientibus ipsis, where ipsis may mean nobis O. R., as Caesar is here associated with civitas.-Tac. H. 4, 76 Civilis dicit: Germanos, qui ab ipsis (- Civ. and bis party) sperentur, non iuberi, non regi, sed cuncta ex libidine agcre.-Curt. 3, 7, 9 Parmenio censebat . . plunitiom ipsis (=P. and his soldiers) camposque esse vitandos. It is true that in these passages and in many like them, the Reflexive would not necessarily indieate a Plural (nos, nobis, ctc.), but in none of them is the Intensive used merely to avoid ambiguity, and in every instance there is, as usual, an iden of comparison, of opposition expressed or easily implied, a contrast of some kincl.

And such everywhere is the usage of the best authors. In the later language are found examples of ipse used instend of the Reflexire, without pereeptible difference in sense. This is especially true of Curtius. Examples arc: $3,1,8$ sexaginta dierum indutias pacti, ut, nisi intra cos auxilium Dareus ipsis misissct, dederent urbem. 7, 6, 1s illi nec de fide nec de potentia regis ipsos dubitare respondent. $T, 8,8$ nuntiare iubent regi velle ipsos ad cum mandata perferre. 10, 2, 10 illi tentari ipsos rati.-Ce. Sen. Ep. 6 sciunt ipsos omnia habere communia.

\section{Pronouns of the First and Second Persons.}

The Pronouns of the First Person oceur in the O. O. only when the Reporter refers to himself, or alludes to what is said about him or imputed to him :-Cic. Fam. 11, 1, 1 Antonius se neque mithi provineiam dare posse aicbat neque arbitrari tuto in urbe esse quemquam nostrum.-Nep. 15, \pm , \pm istud finciam, ne aliquis dicat id ad me ereptum pervenisse.

In like manner the Pronouns of the Second Person occur in 
the O. O. only when a statement is made to a Second Person of what he has himself said, or of what is said about him :Cic. Q. Fr. 1, 2, 10 Flavius mihi dixit te ad procuratores suos litteras misisse. De Sen. 3 sed fortusse dixerit quispiam titi propter opes...... tuam tolerabiliorem senectutem videri.

Otherwise, the various pronouns of the Third Person stand as representatives of the pronouns of the First, Second, or Third Persons of the Direct form, - the Reflexive reproducing the Speaker, the Demonstrative the person addressed, and the various pronouns of the Third Person the object spoken of. When emphasis or contrast is necessary, the Distinctive ipse is employed to represent any of the three Persons. The O. O. period should be considered, then, as a Subordinate clause or a series of such cliuses, having as a rule Subjects and Objects in the Third Person, with pronouns regularly employed according to the rules of Subjective and Objective reference. And so it often happens that in the Subordinate cliuses of $O$. O., the Reflexive must be used to represent, not only the Speaker, but also the person addresed, or the person spoken of. This is true in all cases when a pronoun refers to the Subject of the clatuse in which it stands, regardless of the original Person of the predicate :-Liv. 2, 6, 2 (Tarquinius orare) : ne se (O.R. me) ante oculos suss (O. R. vestros) perire sincrent $;. . . \ldots$ alios Romam accitos......en inter se (referring to eos) partes regni rapuisse (where the Reflexives represent the three different Persons of a Direct form). It is ascless to multiply cxamples. It should be noted that when the Speaker is made to refer not so much to himself as to his party, his nation, or people, nos, noster of the $O$. R. may be retained. 'This is very common in the Historians, and especially Caesar:-B. G. 1, 11, 3 legati dicunt: ita se a populo Romano meritos esse, ut paene in conspectu excrcitus nostri (=pop. Rom.) agri vastari non debuerint. $1, \pm 6,4$ qua arrogantia Ariovistus usus omni Gallia Romanis interdixisset impetumque in nostros (= Romanos) cius equites fecisscit. In B. G. 1, 43 Cacsilr, who is speaking, first uses " suc (=meri) senatusque beneficia," "beneficio ac libcralitate sue (=-mea) ac senatu."; be then employs the distinctive ipsis (=nobis), latel' 
" nostram amicitiam," and finally " amicitiam populi Romani." In chapter 44 , where Ariovistus replies, the name Roman people is used five times, and then $(\$ 8)$ follows : Provinciam suam hanc esse Galliam, sicut illam nostram (Romanam). Ut ipsi concedi non oporteret, si in nostros (Rom.) fincs impetum fraceret, sic item nos (R.) esse iniquos, ete. Cf. $4,3 \pm, 5$ paucitatemque nostrorum militum suis praedicaverunt et, quanta sui liberandi facultas daretur, si Romanos castris expulissent, demonstraverunt. It is evident that in the last two examples nos, etc., do not refer at all to the Speakcr. We, our, us must always in such cases be taken from the standpoint of the Romans, no matter who is speaking. Cf. B. G. 1, 17, 5 Liseus proponit : ab eisden nostra consilia hostibus enuntiari-where nostra refer's to the Romans, not to $\mathrm{L}$. and his people. Liseus is referred to by se, sese, and his people are mentioned by name, Acduis. In B. G. 1, 22, 3 nostress is restricted to the part of the army under Caescar's command: Labienus (with his two legions) monte occupato nostros cxspectabat, etc.; and in the next sentence (Cacsar cognovit montem a suis teneri) suis refers to the legions under Labienus. Cf. 5, 29, 2-3 nostri, nostras, where Cacsar is not present at all. In the 13. C. suos, etc., (=his men) is usually used when Cacsar is subject $(3,45,4$ suos ; $3,46,1$ suorum) ; otherwise, nostri, etc. $(3,40,1 ; 4 t$, $4 ; 45,5 ; 67,4$, ctc.), always of Caesar's party. To refer to Pompey's party the author uses either Pompeiani $(3,4 t, 4)$, hostis $(1,45,1$ hostem), adversarii $(1,40, \tau ; 3,40,1)$, or very frequently $i l l i(1,45,3 ; 1,6 \pm, 1 ; 3,67,4$, etc.).

Except in the cases mentioned, the Reflexive regularly reproduces the Spenker and the person associated, unless tpsi is used for emphasis or contrast: Tac. H. 4, 14 Civilis dicit: tradi se pracfectis conturionibusque.-Curt. 10, 5, 17 omnium suorum mala Sisigambis una capiebat; flebat simul mortuos vivosque : quem enim pucllarum acturum esse curam? iteram esse se captas, etc.

The Promoun of the Second Person of $O . R$. is reproduced in $O$. $O$. by the Demonstratives is and ille, unless the use of the Reflexive is required by the general rules of Subjective reference. Ille is of course the more emphatic and is used 
oftener in contrasts. It often stands, then, where in $O . R$. the subject pronoun (tu, ros) would be expressed. Ipse is regularly used instead of, or with, the various forms of is, ille when greater emphasis or contrast is needed. See p. 41 .

Is: B. G. 1, 7, 3 rogarc ut eius (=tua) voluntate id sibi facere licent. $1,14,6$ si obsides $a b$ is (vobis) sibi dentur, sese cum iis (vobiscum) pacem esse facturum. 1, 19, 5 sine cius (tui) offensione animi. 1, 3t, 1 velle sese cum eo (tecum) agere. $1, \pm 3, \pm$ sua senatusque in eum (te) beneficia commemoravit.-B. C. 1, 3t, 3 quos Pompeins erat adhortatus, ne nova Caesaris oflicia veterum suorum beneficiorum in cos (ros) memoriam expellerent. 1, 6t, 2 milites centuriones tribunosque militum obsecrare, ut per eos (vos) Caesar certior ficret. (Cf. B. G. 7, 17, \& per eos).-Jug. 109, 2 dicit se venisse quacsitum ab co (to).-Nep. 2, 4,3 ad regem misit, ut ei nuntiarent suis verbis adversarios eius (tui) in fuga esse. 2, 7, 2 (Themistocles) ad ephoros accossit atque contendit fialsa iis (vobis) esse delati. 18, 10,2 cun exercitus ei iurasset, se cum (te) defensurum.-Liv. 1, 41, 5 propediem ipsum cos visuros (videbitis). Cf. 2, 10, 3 nequiquam eos fugere. 1,53 , 7-8 manere is (vobis) bellum...... quod si apud eos (vos) supplicibus locus non sit. $3,47,2$ se pro liberis eorum cotidie in acie starc. $3,98, \mathrm{~S}$ de Sabino bello cos referre.

Ille: B. G. 1, 3, 7 se illis regna conciliaturum confirmat. $1,43,5$ illum ea praemia consecutum (ta consecutus es). 1 , $\pm t, 11$ sese illum non pro anico, sed hoste habiturum. $1, \pm t$, 13 magno se illum praemio remuneraturum. 7, 20, 2 reguum illum Galliae malle (tu mavis) Caesaris concessu.-B. C. 3, 10, 5 illum Italia expulsum.-Jug. S, 2 Scipio dixit : ultro illi et gloriam et regnum venturum. 11, 6 tum idem Hiempsal placere sibi respondit; nam ipsum illum ( $=$ tu ipse) in regnum pervenisse. 33,4 velle manufesta magis ex illo habere...... in fide populi Romani magnam spem illi sitam. 51, 4 hortari milites, ne deficerent: neque illis castra esse neque, etc. 77 , 1 legati ad Metellum venerant: ni id festinaret, in summo periculo suam salutem, illorum socios fore (where there is a change from O. R. tuns to vester $=$ tuus (Metelli) et Romanorum). See further 56,4 illis, illos; 61,5 illi ; 62,1 illo; 
62,3 illius ; 64, 2 illi (bis); 64, 4 illum ; 65, 3 illum ; 68, 3 illos; $79, \mathrm{~s}$ illi ; 106, 1 illis; 111,1 illi.-Nep. 1, 1, 5 illi responderunt tum id se fucturos, cum ille venisset Lemnum. 4, 4, 6 nec se meritum de illo optime proderet. 22, 1, $5 \mathrm{cum}$ Catulus negaret bellum compositurum, nisi ille cum suis Sicilia desederent, etc. $23,10,5$ id illos fruile serpentium multitudine consccuturos.-Liv. 1, 9, it illas tamen in matrimonio fore. 1, 25, 1 quicquid civium sit, illorum tunc arma, illorum intueri manus. 2, 15, 2 cum ille peteret. 2, 56,16 non vim suam illis tempus adempturum. $3, \pm 0,4$ multo id migis se illius causa orare quim rei publiche.

A count through the Cat. and Jug., sereral books of Caesar and Livy, and a number of the Lives, shows that Livy uses ille and is with nearly equal frequency; that Caesar and Nepos more often perhaps use is (cspecially the form eius); and that Snllust almost never uses is. As a rule, is, except in Sallust, is more frequent in Dependent Clauses allied to Indirect Discourse than in the formal Oratio Obliqua. Sometimes both pronouns are employed in the same context:-B. G. 1, 4t, 11--13 scse illum non pro amico, sed hoste habiturum; quod si eum interfecerit. . . . . eius morte..... magno se illum pracmio remuneraturum ...... sine ullo eius labore.-Nep. 2, T, 2 (Themistocles) ad cporos accessit atque contenclit falsa iis esse delata: quare acquum esse illes viros mittere, etc. 10, 8, 2 Callicrates adit ad Dionem et ait : eum magno in periculo esse .....alicui suorum negotium daret, qui se simularet illi inimicum..... guod inimici eius, etc.

When nos, noster, etc., of O. R. include the Speaker and the Person addressed, they are reproduced in $O . O$. (1) by the Reffexive, as Jug. 62, 1 Bomilcar obtestatur, ut sibi (Jug.) liherisque et genti Numidarum provideat: omnibus proeliis sese (O. R. nos $=$ ego ot $\mathrm{ta})$ victos, etc. 70, 5 Bomilcar litteras (ad Nabdalsam) mittit: Iugurtbae exitium adesse; ceterum, stume $(=0$. R. nostra $=$ mea et tua $)$ an Metelli virtute periret, id modo agitari-or (2) by the Dimonstrative, as B. G. $1,47,1$ Arioristus ad Caesarem legatos mittit : velle se de his rebus, quae inter cos (me et te) agi coeptae neque perfectre essent-or (3) the Inflection alone may show the 
transition from Singular to Plural, as Nep. 2, 4, 2 Themistocles unus restitit ct [sc. $s e=\operatorname{nos}=$ ego et ros of $O$. R.] universos pares esse posse aiebat, dispersos testabatur perituros. Cf. Jug. 106, 4 cetcrum ab eodem monitus, uti proficiscerentur (where the probable Direct form was, "(te) moneo, ut proficiscamur"').

\section{Froper Name or Other Noun Used Instead of Pronoun.}

It is worthy of note that frequently the Latin authors for emphasis or clearness used in 0 . O. a Proper Name or other Noun instead of the various Pronouns representing the different Persons of the O. R. They were no doubt often prompted to do this on account of a possible confusion that would result from the accumulation of Pronouns of the Third Person. Somciimes the Name may be an original (i. e., O. R.) Vocative; at other times it may have been, for some reason, actually nsed in the $O$. R. as subject or object. As the discussion of this subject is more the province of an essay on style than of a study in grammar, only a few examples from the various anthor's will be cited:-B. G. 1, 1t, 1 legati Helvetii (whom Caesar is addrossing). 1,20,4 quod si quid ei a Cacsare gravius accidisset (he is speaking to Cacsar ; but ei, immediately before, refers to Dumnorix). 5, 53, 7 de victoria Cacsaris (although Caesar is Grammatical subject; but suus has been twice used to refer to Roscius, the Logical sulbject). -B. C. 1, 8, 3 Cacsuri, Cacsarem (person addressed)._Jug. 81, 1 candum illos (Romanos) cuusam belli cum Bocche (person addressed) habere quam secum (Iugurtha). Cf. Liv. 24, 29, 12 itaque integro secum (Syracusinis) foedere bellum Romanos (persons addressed) cum iis (Leontinis) gesturos._Lir. 26, 29, \pm (Siculi quacrebant) : quid iratum (Marcellum), quod Romam de se (M.) questum venisse Siculos (the speakers) sciat, fincturum? 32, 11, 7 quattuor millia inde lecta perlitum et trecentos oquites tribuno militum tradit: equites, quoad locu patiantur, ducere inbet; ubi ad invia equiti ventum sit, in planitie aliqua locari equitatum; pedites qua dux monstraret viam ire. Here pronouns would not make clear the sense, and repetition 
is certainly necessary. Cf. the remarkable passage in Liv. 9, 33, S-9 (lex Aemilia, eos censores, illos censores, eam legem, aut se aut corum quemquam, eam legem, censores, ea lege).

Whenever there is a quotation in the O. O., the Name is naturally retained, as in ecrtain of the above passages and in the following: B. G. 2, 14, 1-3. Divitiacus facit verba : "Bellovacos impulsos ab suis principibus, qui dicerent, 'Accluos ab Caesare [whom Div. (not principes) is addressing] in servitutem redactos"....." etc.-B. C. 1, 10 (consules Ponpeiusque) ad eum (Cacsurem) mandata remittunt, quorum hace crat summa: Cacsur in Galliam reverteretur...... Pompeium in Hispanias iturum......Caesarem facturum..... nou intermissuros consules Pompcianque delectus [the proposal is quoted objectively throughout, as if not addressed to Caesar (ille, illum) by Pompey (se) and the consuls (se) ]. 3, 43 , 3 ut auctoritatem minueret, cum fama percrebuisset, illum a Cacsare ( $=$ ab se) obsideri (Cacsar's purpose, but the words of the repont are quoted). Cf. B. G. 1, $3 \pm$ and 36 , where the Envoys usc Arionistus' words: Cinesur, a Caesare, Caesarem, etc.

Hic, Nunc, Hodie, etc.

In the Indirect Discourse hic of the Direct regularly becomes ille (is); nuno becomes tum, tunc; hodie becomes illo (eo) die; and in like manner the various pronouns and adverbs of similar meaning are changed to represent the changed conditions of Time and Place in which the Reporter speaks or writes:-Cic. in Verr. 4, 29, 67 rex clamere coepit candelabrum ab se C. Verrem abstulisse: id tum in illo conventu civium Romanorum dare Iovi.-B. G. 1, 44, 4 Ariovistus dixit : iniquum esse de stipendio recusare, quod ad $i d$ tempus pependerint. Cf. B. C. 1, 24, 5 quoniam ad $i d$ tempus filcultas collocnendi non fucrit.--B. G. 4, 11, 5 non longius processurum eo die (O. R. hodie) dixit...... postero die (O. R. cras) convenirent. Cf. $6,7,6$ postero die.-B. C. 1, 7, 5 quarum rerum illo tempore nihil factum. 2, 3t, 5 memoria tenerent milites en, quac pridic (O. R. heri) sibi confirmassent.-Jug. 49,3 itlum diem (O. R. hic dies) omnes labores et victorias 
confirmaturum. 109, 3 post diem decumum redire iubet, ac nihil etiam tum (O. R. adhuc) decrevisse. 81, 1 tum sese, paulo ante Carthaginienses, post, etc. Cf. 83,1 babere tum copiam; 102, 14 ac tum legatos missurum.-Liv. 1, 50, 8 quia res exemisset illum diem. 3, 61, 1 illo die primum liberos pugnare. Cf. 10, 41, 11 illo die. 3, 62, 1 si tum (O. R. nunc) non sint. 29, 1,6 malle eos iam tum fateri. 25, 22, 10 ut tunc saltem opem ferret. $22,5,2$ nec enim inde (O. $R$. hinc) votis...... sed virtute evadendum esse.-Tac. H. 5, 17 illum diem (O. R. hic dies) aut gloriosissimum aut ignominiosum fore.

Hic, nunc, etc., are not seldom retained in the Indirect form. This is the rule when reference is made to what immedintely precedes, as in B. G. 1, 18, 4 his rebus ; 1, 18, 6 huius potentiae. 1,31, 3 fuctiones esse duas: harum alterius principutum, etc.-B. C. 3, 10, 11 haec quo facilius probari possent-and very frequently in all the authors. Thus a writer employs hic, etc., to lend animation, where $i l l e$, etc., might otherwise have been used :-B. G. 5, 27, 7 habere nunc se rationem. $1,40,3$ cur hune quisquam ad officio discessurum iudicaret. Cf. ibid. \& 6 hos; $\$ 7$ hos; $\$ 8$ hos.B. C. 1, 9, 4 quonam haec omnia pertinere. Cf. ibid. \$3 hano iacturam. 3, 10, 7 hoo unum esse tempus.-Nep. 23, 7, 3 quod Hannibalem etiamnunc haberent. Cf. Liv. 23, 22, 7 esse ctiamnunc virum. Nep. 20,5, 3 dixit nunc demum se voti esse damnatum : namque 100 a diis immortalibus precatum, etc. See further Nep. 7, 11, 4-6 hos, in his rebus, horum, in his; and 18, 11, 3 hoc.-Liv. 3, 72, 3-5 hoc legatos referre domum, hoc vulgari; Scaptione hoc assignaturos putarent finitimos populos-hac imagine-hoc, etc. 6, 17, 3 hocine patiendum fuisse? $22,38,9$ minari se qui dux iam nunc togatus in urbe sciret, etc.

Sometimes, however, there are special reasons for the retention of hic, etc., and this is frequently necessary for clearness or proper contrast:-B. G. 1, 31, 10 quod Ariovistus tertiam-partem agri Sequani occ upavisset et nunc de altera parte tertia? Seq uanos decedere iubet (nunc contrasts the time of seizure of the first third and the time of the present atteppt). $1,3 \mathrm{f}, \mathrm{c}$

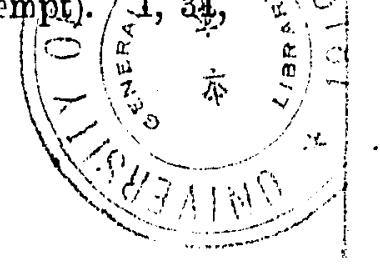


11 neque hano consuetudinem victus cum illa comparandum (hanc is necessary on account of illa). Cf. 1, 44, S provinciam suam hane esse Galliam sicut illam nostram. 2, 4, 7 nune esse regem Galham (cum......tum preceding probably led to retention of nunc).-B. C. $1,85,5$ neque nunc se postulare (following ante paulo). 1, 85, 11 omnia et se tulisse et esse laturum ; neque nunc id agere (contrast of past, future, and present).-Jug. 111, 1 quam nunc peteret, tunc ultro adventuram.-Liv. 8, 31, 3-4 et tune..... et nunc. 5, 2, 3 hoc illud esse, quod aera militibus sint constituta (hoc necessarily retained, as illud illad would be intolerable. Cf. Liv. Praef. 10 hoc illud est, etc.). 2, 32, 9 tempore, quo in homine non, ut nunc, omnia in unum consentientia (tunc would not be allowable, as the fact is true not only of the time of Menenius Agrippa, but of course also of the time when Liry writes).Curt. 7, 7, 29 tum sollicitudinis causas apparuisse, nunc egregie litatum esse. In Curt. 7, 10, 6 nuno is properly retained after an unreal conditional sentence to state the actual fact $=$ but as it is. But in B. G. 4, 19, 3 hic Romanorum adventum exspectare atque $i b i$ decertare constituisse (Suebos), 一hic and $i b i$ refer, strange to say, to the same place. Cf., however, 5, 43, 5, where a similar use is found in O. R. : lic dies gravissimus fuit, sed tamen hunc habuit eventum, ut eo die, etc.-On the other hand, certain expressions cannot be retained. For instance, B. G. 4, 11, 5 processurum eo die dixit: huc postero die convenirent, - though Caesar retains huc, he must use eo, postero die, not hodie, cras. 